Bodo Moritz, Hauke Lilie, Isabel S. Naarmann-de Vries, Henning Urlaub, Elmar Wahle, Antje Ostareck-Lederer and Dirk H. Ostareck*

\title{
Biophysical and biochemical analysis of hnRNP K: arginine methylation, reversible aggregation and combinatorial binding to nucleic acids
}

\begin{abstract}
Analysis of arginine methylation, which affects specific protein interactions in eukaryotic cells, requires access to methylated protein for biophysical and biochemical studies. Methylation of heterogeneous nuclear ribonucleoprotein $\mathrm{K}$ (hnRNP K) upon co-expression with protein arginine methyltransferase 1 in $E$. coli was monitored by mass spectrometry and found to be identical to the modification of hnRNP K purified from mammalian cells. Recombinant non-methylated and arginine-methylated hnRNP K ( ${ }^{\mathrm{Meth}}$ RNNP K) were used to characterize self-aggregation and nucleic acid binding. Analytical ultracentrifugation and static light scattering experiments revealed that hnRNP $\mathrm{K}$ methylation does not impact reversible self-aggregation, which can be prevented by high ionic strength and organic additives. Filter binding assays were used to compare the binding of non-methylated and ${ }^{\text {Methn- }}$ RNP $\mathrm{K}$ to the pyrimidine repeat-containing differentiation control element (DICE) of reticulocyte 15-lipoxygenase mRNA 3' UTR. No affinity differences were detected for both hnRNP K variants. A series of oligonucleotides carrying various numbers of $\mathrm{C}_{4}$ motifs at different positions was used in steady state competition assays with fluorescently-labeled functional differentiation control element (2R). Quantitative evaluation indicated that all hnRNP K homology domains of hnRNP $\mathrm{K}$ contribute differentially
\end{abstract}

*Corresponding author: Dirk H. Ostareck, Department of Intensive Care and Intermediate Care, University Hospital, RWTH Aachen University, Pauwelsstrasse 30, D-52074 Aachen, Germany, e-mail: dostareck@ukaachen.de

Bodo Moritz, Hauke Lilie and Elmar Wahle: Institute of Biochemistry and Biotechnology, Martin Luther University Halle-Wittenberg, D-06120 Halle, Germany Isabel S. Naarmann-de Vries and Antje Ostareck-Lederer: Department of Intensive Care and Intermediate Care, University Hospital, RWTH Aachen University, Pauwelsstrasse 30, D-52074 Aachen, Germany

Henning Urlaub: Max-Planck-Institute for Biophysical Chemistry, Bioanalytical Mass Spectrometry Group, D-37077 Göttingen, Germany; and Bioanalytics, Department of Clinical Chemistry, University Medical Center, D-37075 Göttingen, Germany to RNA binding, with $\mathrm{KH} 1-\mathrm{KH} 2$ acting as a tandem domain and $\mathrm{KH} 3$ as an individual binding domain.

Keywords: arginine methylation; heterogeneous nuclear ribonucleoprotein K; hnRNP K homology domains; RNAbinding domain; self-aggregation; steady state nucleic acid-interaction.

DOI 10.1515/hsz-2014-0146

Received February 17, 2014; accepted May 20, 2014

\section{Introduction}

Heterogeneous nuclear ribonucleoprotein K (HnRNP K) was first described as part of nuclear ribonucleoprotein (RNP) complexes associated with heterogeneous nuclear RNA (Pinol-Roma et al., 1988; Matunis et al., 1992). The protein contains three hnRNP K-homology $(\mathrm{KH})$ domains consisting of 65-70 amino acids (Gibson et al., 1993; Siomi et al., 1993; Dejgaard and Leffers, 1996; Musco et al., 1996). KH domains represent the most prominent RNA-binding domains besides the RNA recognition motif (Ostareck-Lederer et al., 1998; Clery et al., 2008). They are conserved from yeast to mammals, and there are some structural differences in prokaryotes (Valverde et al., 2008). The functional relevance of $\mathrm{KH}$ domain binding to ssDNA and ssRNA has been shown in systematic analyses (Braddock et al., 2002; Makeyev and Liebhaber, 2002; Backe et al., 2005; Messias et al., 2006). Two structural variants with a common $\beta \alpha \alpha \beta$ core (Grishin, 2001) were determined for $\mathrm{KH}$ domains. The type I fold $\left(\beta_{1} \alpha_{1} \alpha_{2} \beta_{2} \beta_{3} \alpha_{3}\right)$ of hnRNP K KH3 binds nucleotides in a cleft between $\beta$-sheets and $\alpha$-helices (Baber et al., 1999; Messias and Sattler, 2004). Structural information was obtained from $\mathrm{X}$-ray and nuclear magnetic resonance analyses of KH3 in complex with CT-rich DNA (Backe et al., 2005; Messias et al., 2006). Sequential evolution of ligands by exponential enrichment experiments indicated high-affinity 
KH3 binding to UC ${ }_{3-4}$ RNA (Thisted et al., 2001). HnRNP K and the two highly homologous proteins, hnRNP E1 and hnRNP E2 (82\% identity) (Kiledjian et al., 1995; Leffers et al., 1995; Ostareck et al., 1997; Messias et al., 2006), constitute the main poly(C)-binding activity in mammalian cells. Nucleic acid binding affinities of full-length proteins are in the nanomolar range, while $\mathrm{K}_{\mathrm{D}}$ values for isolated $\mathrm{KH}$ domains are micromolar (Backe et al., 2005; Sidiqi et al., 2005). This indicates stabilized interactions in the full-length protein. The presence of several RNAbinding domains is a typical feature of RNA-binding proteins, which complicates the analysis of substrate specificity and the contribution of individual domains to RNA-binding affinity.

Besides KH domains, hnRNP $\mathrm{K}$ bears an $\mathrm{N}$-terminal bipartite nuclear localization signal and hnRNP K-specific nuclear shuttling signal, which confer bi-directional nuclear-cytoplasmic transport capacity (Michael et al., 1995, 1997). HnRNP K is implicated in the regulation of mRNA synthesis, processing and translation. Regulation of c-Myc (Michelotti et al., 1996; Tomonaga and Levens, 1996) and eIF4E gene transcription (Lynch et al., 2005) by hnRNP $\mathrm{K}$ depends on ssDNA-binding activity and oligo(CT) promoter motifs (Michelotti et al., 1996). The importance of ssDNA-protein interactions has been supported in recent analyses of R-loop-forming sequences (Thomas et al., 1976), where transient DNA/ nascent RNA hybrids leave the non-template strand unpaired at transcription sites (Ginno et al., 2012; Wongsurawat et al., 2012). R-loop-forming sequences were detected at c-Myc gene translocation sites in lymphoma (Duquette et al., 2005; Kanno et al., 2005). HnRNP $\mathrm{K}$ also contributes to p53-dependent transcription regulation in DNA damage response (Huarte et al., 2010). There, phosphorylation by ATM kinase antagonizes hnRNP K ubiquitination and proteasomal degradation (Moumen et al., 2005, 2013). In a global analysis (Venables et al., 2008), and specifically in Bcl-x pre-mRNA processing (Revil et al., 2009), functions of hnRNP $\mathrm{K}$ in alternative splicing became evident.

Furthermore, hnRNP K functions in mRNA-specific translation regulation. In erythroid precursor cells, DDX6 recruits reticulocyte-15-lipoxygenase (r15-LOX) mRNA to translational inactive mRNPs (Naarmann et al., 2010) until newly-synthesized r15-LOX is required to initiate mitochondria breakdown as terminal step in erythrocyte differentiation (Maretzki et al., 1986; van Leyen et al., 1998). HnRNP K and hnRNP E1 bind pyrimidine repeats in the differentiation control element (DICE) of r15-LOX mRNA 3'UTR. Both proteins inhibit translation initiation (Ostareck et al., 1997, 2001). Phosphorylation by c-Src and cleavage by caspase-3 lead to release of hnRNP K from the DICE as a prerequisite for the initiation of r15-LOX synthesis (Ostareck-Lederer et al., 2002; Messias et al., 2006; Adolph et al., 2007; Ostareck-Lederer and Ostareck, 2012; Naarmann-de Vries et al., 2013). In addition, hnRNP K and hnRNP E1 stimulate c-Myc protein synthesis by direct interaction with a C-rich sequence in the internal ribosome entry site of c-Myc mRNA (Evans et al., 2003).

Protein arginine dimethylation is a common posttranslational modification in eukaryotes. Protein arginine methyl transferases (PRMTs) catalyze the methyl-group transfer from S-adenosylmethionine (SAM) to substrate arginines (Gary and Clarke, 1998; Bedford and Richard, 2005; Bedford and Clarke, 2009). Type I PRMTs mediate asymmetric $N^{G}, N^{G_{-}}$and type II PRMTs symmetric $N^{G}, N^{g_{-}}$ arginine dimethylation. Protein arginine N-methyltransferase 1 (PRMT1) generates the majority of asymmetric dimethylarginine residues (Tang et al., 2000).

Among other hnRNPs, hnRNP K was shown to contain methylated arginine residues (Liu and Dreyfuss, 1995; Huang et al., 2002). Ong et al. (2004) detected dimethylation of R296 and R299, but the asymmetric state and quantitative distribution were not described. Furthermore, the biological function of hnRNP $\mathrm{K}$ methylation remained elusive. Mass spectrometry analysis and Edman degradation of hnRNP K purified from HeLa cells identified five quantitatively asymmetrically dimethylated arginine residues (R256, R258, R268, R296, and R299). In addition, R303 was asymmetrically dimethylated in $<33 \%$ and R287 was monomethylated in $<10 \%$ of purified hnRNP K (Ostareck-Lederer et al., 2006). PRMT1 was identified as the only enzyme that catalyzes quantitative asymmetric hnRNP $\mathrm{K}$ arginine dimethylation in vitro and in vivo (Ostareck-Lederer et al., 2006). After in vitro methylation of recombinant hnRNP K by PRMT1, R296 and R299 were also identified as asymmetrically dimethylated by mass spectrometry (Chiou et al., 2007).

Arginine methylation did not influence the RNA-binding activity of hnRNP K, its translation inhibitory function or cellular localization. The hnRNP $\mathrm{K}$ interaction with tyrosine kinase c-Src was, however, diminished resulting in inhibition of c-Src activation and hnRNP K phosphorylation (Ostareck-Lederer et al., 2006). These findings support a role of arginine methylation in the regulation of protein-protein interaction.

Immunoprecipitation and in vivo reporter assays suggest a modulating function of hnRNP $\mathrm{K}$ methylation on p53 co-activator activity (Chen et al., 2008; Chan et al., 2009). HnRNP K methylation in DNA damage response increased the affinity for p53 and inhibition of methylation attenuated $\mathrm{p} 53$ promoter recruitment (Chen 
et al., 2008). The binding of hnRNP $\mathrm{K}$ to Epstein-Barr virus nuclear antigen 2 requires hnRNP $\mathrm{K}$ methylation (Gross et al., 2012). The interaction domains of both proteins bear asymmetrically dimethylated arginines. Association with hnRNP K enhances the Epstein-Barr virus nuclear antigen 2-dependent activation of the viral latent membrane protein $2 \mathrm{~A}$ promoter (Gross et al., 2012).

The in vitro analysis of arginine methylated proteins is challenging, due to limited access to modified protein. Here, we present a feasible technique for largescale preparation of recombinant methylated hnRNP K. The comparison of quantitatively methylated hnRNP $\mathrm{K}$ prepared by that method with non-methylated protein revealed that the modification has no effect on reversible hnRNP K aggregation. Furthermore no impact on RNA binding could be detected. Quantitative comparison of a series of ssDNA and ssRNA ligands demonstrated combinatorial binding of hnRNP K KH domains to multiple C motifs.

\section{Results}

\section{Expression of quantitatively arginine meth- ylated hnRNP K in Escherichia coli}

To analyze the impact of hnRNP $\mathrm{K}$ arginine methylation on its interaction with other proteins (Bomsztyk et al., 2004) and hnRNP K self-association (Kim et al., 2000) biochemically, sufficient amounts of quantitatively methylated protein are required. To overcome this limitation, an in vivo expression system that provides the capacity for efficient and specific quantitative methylation was developed. Methylated hnRNP K suitable for interaction studies was generated by co-expression from a tricistronic plasmid that encoded PRMT1 and hnRNP K in a 2:1 ratio in Escherichia coli. To facilitate quantitative arginine methylation by PRMT1, induced protein expression was blocked at different times by erythromycin treatment and methylation was extended under continued cultivation (Figure 1A). Methylated hnRNP $\mathrm{K}$ and non-methylated hnRNP $\mathrm{K}$ expressed in the absence of PRMT1 were partially purified by His-affinity chromatography (Figure 1B, lower panel). To determine the methylation status of purified hnRNP K, $\left[{ }^{14} \mathrm{C}\right] \mathrm{SAM}$ was used as methyl donor in a PRMT1-dependent in vitro methylation assay. Reduced $\left[{ }^{14} \mathrm{C}\right]$-methyl incorporation reflects increased arginine methylation of the purified protein (Ostareck-Lederer et al., 2006; Fronz et al., 2008). Prolonged protein synthesis resulted in slightly enhanced hnRNP K methylation (Figure 1B, lanes 1-10 and Figure 1C). Extended E. coli cultivation following erythromycin-mediated inhibition of mRNA translation, however, substantially enhanced methylation state of the protein, resulting in hardly detectable $\left[{ }^{14} \mathrm{C}\right]$-methyl incorporation in vitro (Figure 1B, lanes 11-20 and Figure 1C). In contrast, $\left[{ }^{14} \mathrm{C}\right]$-methyl incorporation in non-methylated hnRNP $\mathrm{K}$ approached $100 \%$, as calculated from the number of in vivo methylated arginine residues (Ostareck-Lederer et al., 2006) (Figure 1B, lanes 21-25 and Figure 1C).

For subsequent experiments, quantitatively methylated hnRNP K (MethnRNP K) and non-methylated hnRNP $\mathrm{K}$ were expressed on 6 liter fermentation scale for $4 \mathrm{~h}$ and cultivation of $E$. coli was extended for $2 \mathrm{~h}$ following erythromycin treatment (see Materials and methods). Proteins were purified to homogeneity on a His-affinity matrix followed by conventional hydroxyapatite and cation exchange chromatography (Figure 1D, left panel). Arginine methylation was confirmed with antibodies that detect asymmetrically dimethylated arginine, ${ }^{\text {MethnRNP }}$ $\mathrm{K}$ or non-methylated hnRNP K specifically (Naarmann et al., 2008; Gross et al., 2012) (Figure 1D, right panel). To identify methylated arginine residues, electrospray ionization quadrupole time of flight mass-spectrometry of tryptic peptides and Mascot ${ }^{\circledR}$ analysis were employed. Identified peptides covered $82 \%$ of the total hnRNP K sequence (Figure 1E). Methylated peptides identified all arginine residues previously shown to be quantitatively asymmetrically dimethylated by PRMT1 in vivo (R258, R256, R268, R296 and R299) (Ostareck-Lederer et al., 2006). Whereas these residues were exclusively dimethylated, arginine 271 and 316 were detected in their unmodified as well as in their mono- and dimethylated forms. Other arginines, including those identified earlier as partially methylated, R303 and 287 in HeLa cells were not modified (Ostareck-Lederer et al., 2006). Since the mass of full-length hnRNP $\mathrm{K}$ could not be assessed, the in vitro methylation assay was used to calculate the average number of methyl groups per protein. The number of methyl groups transferred to non-methylated hnRNP $\mathrm{K}$ was determined based on the $\left[{ }^{14} \mathrm{C}\right]$-signal following calibration to $\left.{ }^{[14} \mathrm{C}\right] \mathrm{SAM}$ (Kolbel et al., 2012). When $11( \pm 2)$ methyl groups were incorporated, hnRNP K methylation was saturated (Figure 1F). This number matches the results of in vivo methylation analyses (OstareckLederer et al., 2006). Recombinant MethnRNP K modified by PRMT1 co-expression was barely methylated in the in vitro assay. After $3 \mathrm{~h}$, less than one methyl group was incorporated per molecule, indicating that ${ }^{\text {MethnRNP }}$ $\mathrm{K}$ was nearly quantitatively methylated by optimized PRMT1 co-expression in E. coli (Figure 1F). 
A Time line

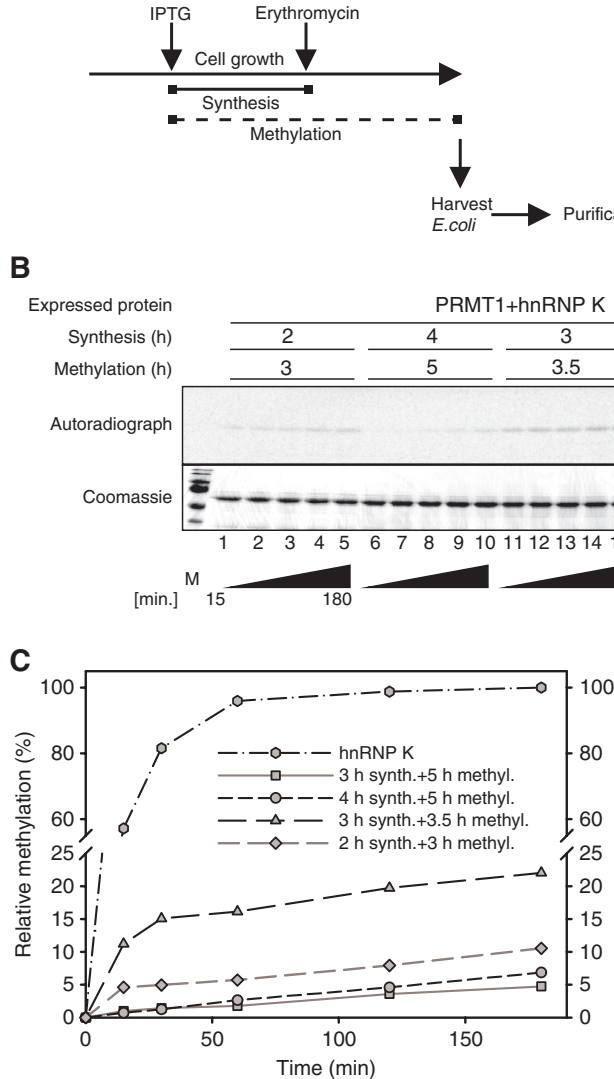

E

1 MGSSHHHHHH SSGLVPRGSH MASETEQPEE TFPNTETNGE FGKRPAEDME 51 EEQAFKRSRN TDEMVELRIL LQSKNAGAVI GKGGKNIKAL RTDYNASVSV 101 PDSSGPERIL SISADIETIG EILKKIIPTL EEGLQLPSPT ATSQLPLESD 151 AVECLNYOHY KGSDFDCELR LLIHOSIAGG IIGVKGAKIK ELRENTOTTI 201 KL FOECCPHS 251 FYDETYDYGG FTMMFDDRRG RPVGFPMRG $R$ GGFDRMPPG $R$ GGRPMPPSRR 301 DYDDMSPRRG PPPPPPGRG RGGSRARNLP LPPPPPPRGG DLMAYDRRGR 351 PGDRYDGMVG FSADETWDSA IDTWSPSEWQ MAYEPQGGSG YDYSYAGGRG 401 SYGDLGGPII TTQVTIPKDL AGSIIGKGGQ RIKQIRHESG ASIKIDEPLE 451 GSEDRIITIT GTQDQIQNAQ YLLQNSVKQY SGKFF
D

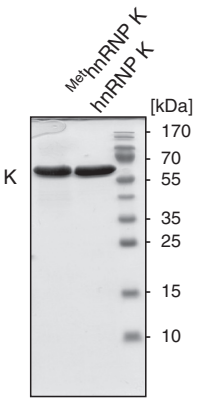

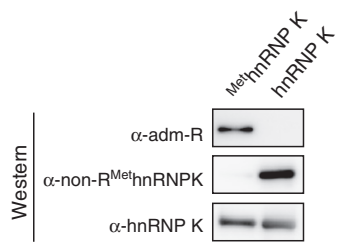

$\mathbf{F}$
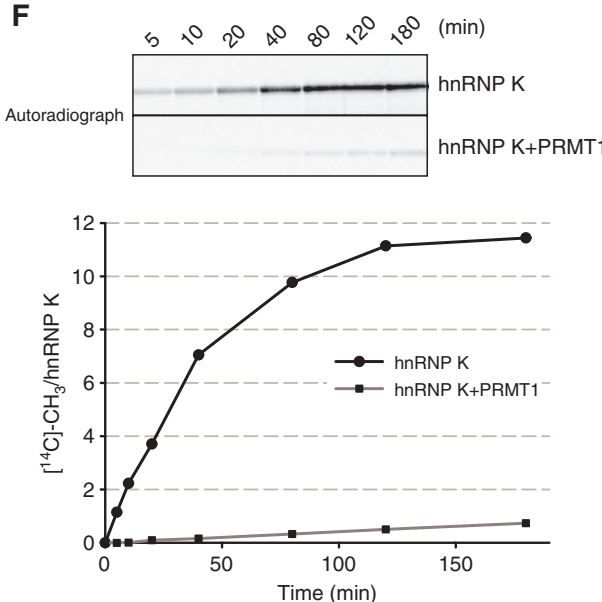

Figure 1 Recombinant expression and purification of quantitatively arginine methylated hnRNP K (MethnRNP K).

(A) Schematic representation of hnRNP K expression, PRMT1-catalyzed arginine methylation and purification from E. coli. (B) HnRNP K was either co-expressed with PRMT1 under the conditions indicated above the gel (lanes 1-20), or by itself (lanes 21-25) and purified. The various preparations were then methylated with purified PRMT1 in vitro; $\left[{ }^{14} \mathrm{C}\right]$-labeled S-adenosylmethionine served as methyl donor. Three $\mu \mathrm{g}$ hnRNP K and $0.6 \mu \mathrm{g}$ PRMT1 were used per assay, and aliquots were withdrawn after $15-180 \mathrm{~min}$. Incorporation of [ $\left.{ }^{14} \mathrm{C}\right]$-methyl groups was analyzed by sodium dodecyl sulfate polyacrylamide gel electrophoresis and autoradiography. Coomassie staining of hnRNP K served as the loading control. (C) Quantification of the data shown in (B). (D) Purified recombinant hnRNP K and MethnRNP K were separated by sodium dodecyl sulfate polyacrylamide gel electrophoresis and analyzed by Coomassie staining (left panel) and by Western blotting (right panel)

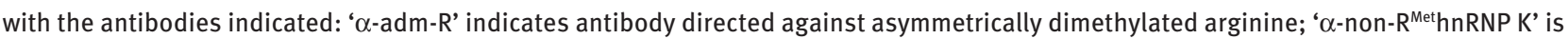
an antibody specifically directed against unmethylated hnRNP K; and ' $\alpha$-hnRNP $K$ ' is an antibody that recognizes hnRNP K independently of its methylation status. (E) Methylated arginine residues in recombinant MethnRNP K were identified by mass spectrometry. Arg 256,258 , 268, 296 and $298($ red $\underline{R}$ ) were quantitatively asymmetrically dimethylated, Arg 271 and $316($ red $\underline{R}$ ) were mixtures of unmodified as well as mono- and di-methylated residues. (F) Purified hnRNP K and MethnRNP K were methylated in vitro as in (B). The autoradiograph is shown in the upper panel and $\left[{ }^{14} \mathrm{C}\right]$-S-adenosylmethionine normalized quantification is shown in the lower panel. 


\section{Reversible aggregation of non-methylated hnRNP K and MethnRNP K}

Self-aggregation of purified hnRNP $\mathrm{K}$ at low ionic strength was detected in the ultraviolet-absorption profile (Figure 2A). The methylation status did not affect aggregation (data not shown; see below), but aggregation was resolved under increased monovalent ion concentration (Figure 2A). To monitor the aggregation process, hnRNP $\mathrm{K}$ was titrated from a $1 \mathrm{M} \mathrm{KCl}$ stock solution into low salt buffer, and static light scattering was determined at $\lambda=320 \mathrm{~nm}$ (Figure 2B). At reduced $\mathrm{KCl}$ concentrations, hnRNP $\mathrm{K}$ aggregate formation increased. The scatter signal immediately reached its maximum and remained constantly high at $150 \mathrm{~mm} \mathrm{KCl}$, indicating very fast aggregation of both MethnRNP K and non-methylated hnRNP K (Figure 2B). When the salt concentration in the starting buffer ( $50 \mathrm{~mm} \mathrm{KCl}$ ) was increased to $500 \mathrm{~mm}$, hnRNP K aggregation was immediately resolved (Figure 2C). The aggregation remained unchanged when $150 \mathrm{~mm} \mathrm{KCl}$ was substituted by $150 \mathrm{~mm}$ KAc and slightly increased by the addition of $50 \mathrm{~mm}$ urea (Figure 2D). However, aggregation was strongly reduced in the presence of di-, tri- or tetracarboxylic acids (Figure 2D). Sucrose or trehalose (10\% $\mathrm{w} / \mathrm{v}$ ) decreased aggregation to a similar extent to citrate (Figure 2D). Analytical ultracentrifugation in optimized buffer (300 mm KCl, $20 \mathrm{~mm}$ Tris- $\mathrm{HCl} \mathrm{pH} \mathrm{8.0,} 50 \mathrm{~mm}$ potassium citrate, $10 \%$ sucrose) revealed that hnRNP K was monodisperse (Figure 2E, left panel) and sedimented as a monomer (Figure 2E, right panel). Sedimentation velocity experiments proved that below $0.5 \mathrm{mg} / \mathrm{ml} \mathrm{hnRNP} \mathrm{K} \mathrm{potas-}$ sium citrate could be omitted to solubilize hnRNP K (data not shown). Several lines of evidence support the notion that hnRNP K aggregation is reversible:

(i) increasing ionic strength resulted in reversed aggregation measured by light scattering (Figure 2B and $\mathrm{C}$ ); and

(ii) hnRNP K was purified under conditions that favored aggregation, but subsequent ultracentrifugation in optimized buffer revealed its monomeric state (Figure 2E).

\section{Interaction of hnRNP K with nucleic acids}

To investigate whether hnRNP $\mathrm{K}$ methylation influences its nucleic acid binding properties, we monitored the interaction with DICE RNA (Ostareck-Lederer et al., 1994). Recombinant MethnRNP $\mathrm{K}$ and non-methylated hnRNP $\mathrm{K}$ as well as both native protein variants purified from $\mathrm{PRMT1}^{+/+}$or PRMT1 ${ }^{-/}$mouse embryonic stem (ES) cells were analyzed. In vitro-synthesized [22P]-labeled DICE RNA was used to determine the apparent dissociation constants in filter-binding experiments (Figure 3). For both variants, ${ }^{\mathrm{Meth}} \mathrm{n} R \mathrm{NP} \mathrm{K}$ and non-methylated hnRNP $\mathrm{K}$, an apparent $\mathrm{K}_{0.5}$ of $4 \mathrm{~nm}$ was detected at $300 \mathrm{~mm} \mathrm{KCl}$ (Figure 3A). Due to the repetitive nature of the DICE RNA sequence, multiple protein binding leads to stronger RNA retention on the filter and induces increased deviations from the simple binding isotherm at high protein concentration. At $300 \mathrm{~mm} \mathrm{KCl}$, however, arginine methylation does not detectably influence RNA-binding affinity. At $1 \mathrm{M} \mathrm{KCl}$ the apparent affinity dropped to a $\mathrm{K}_{0.5}$ of $150 \mathrm{nM}$, and ${ }^{\mathrm{Meth}} \mathrm{h} R \mathrm{NP} \mathrm{K}$ binding shows slightly elevated salt sensitivity. The binding isotherm did not match a bimolecular binding characteristic at $50 \mathrm{~mm}$ $\mathrm{KCl}$, as evident from an apparent Hill-coefficient below one (Figure 3A). This cannot be attributed to a different binding mode, but explained by reversible salt-dependent hnRNP K aggregation: because aggregation is concentrationdependent, the fraction of hnRNP $\mathrm{K}$ active in RNA binding is expected to increase at reduced concentration, which would result in apparent negative cooperativity. The same deviation from a bimolecular binding isotherm was observed for hnRNP K purified from ES $\mathrm{PRMT1}^{+/+}$or ES $\mathrm{PRMT1}^{-1}$ cells (Figure 3B). Aggregation of recombinant and purified cellular hnRNP K (see the Materials and methods section) could not be compared directly due to the limiting yield from eukaryotic cells.

Since arginine methylation has little or no effect on hnRNP K association with RNA, non-methylated protein was used for all subsequent binding experiments. To elucidate how multiple $\mathrm{KH}$ domains contribute to the high affinity for DICE RNA, we investigated the mode and sequence dependence of hnRNP $\mathrm{K}$ association with different nucleic acids. The DICE consists of a ten-fold repeated pyrimidine-rich sequence (190 nts) (Ostareck-Lederer et al., 1994). One repeat (1R) (CCC CAC CCU CUU CCC CAA G) is sufficient for hnRNP K binding and two repeats (2R, $38 \mathrm{nts})$ are necessary and sufficient for translation regulation of reporter mRNAs (Ostareck et al., 1997). 5'-fluorescently labeled DNA ( $\left.{ }^{\mathrm{DNA}} 2 \mathrm{R}\right)$ or RNA ( $\left.{ }^{\mathrm{RNA}} 2 \mathrm{R}\right)$ oligonucleotides were used to measure steady state dissociation constants $\left(K_{\mathrm{D}}\right)$ (Figure 4). HnRNP K titration to a constant amount of ${ }^{\mathrm{DNA}} 2 \mathrm{R}$ or ${ }^{\mathrm{RNA}} 2 \mathrm{R}$ resulted in concentration-dependent fluorescence quenching (Figure 4A). Fluorescence changes were correlated to hnRNP K concentration and $K_{\mathrm{D}}$ values of 2-6 nM were extracted from the exact solution of a reversible bimolecular association (Figure 4A, see Materials and methods). To avoid aggregation, reactions were performed in $300 \mathrm{~mm} \mathrm{KCl}, 20 \mathrm{~mm}$ Tris- $\mathrm{HCl} \mathrm{pH} \mathrm{8.0,} \mathrm{10 \%}$ sucrose. Binding curves were almost identical between

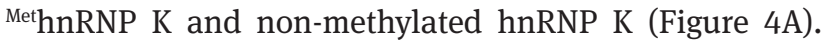


A
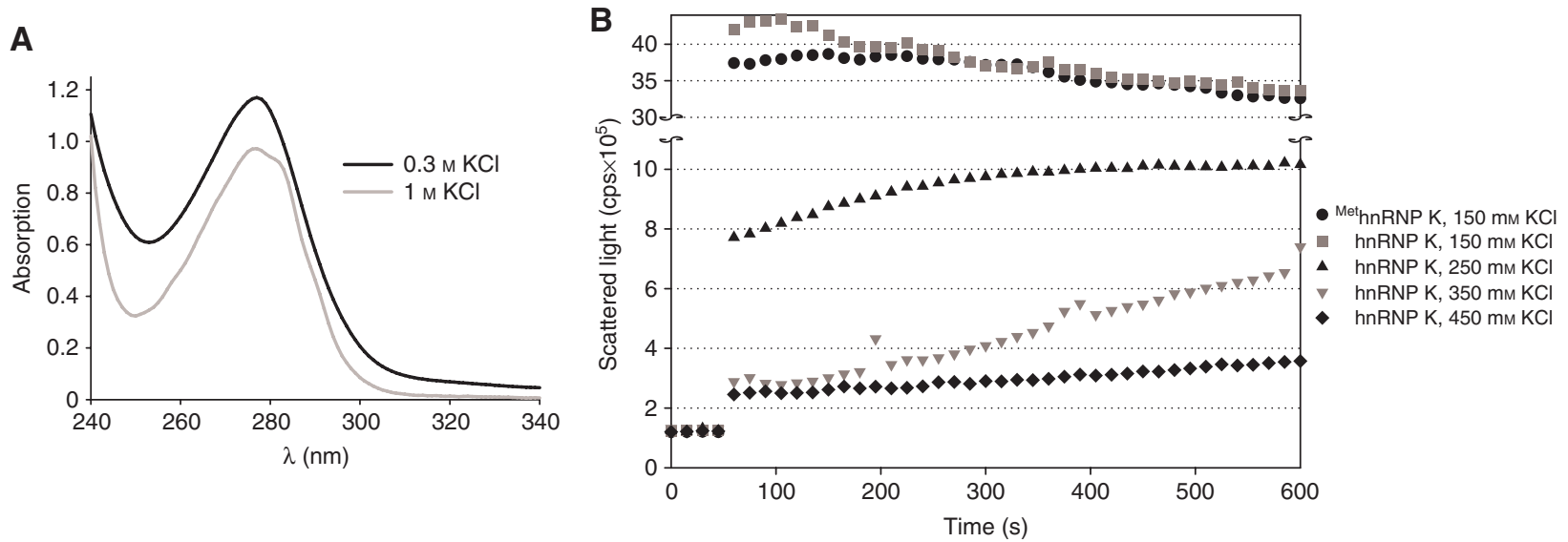

C

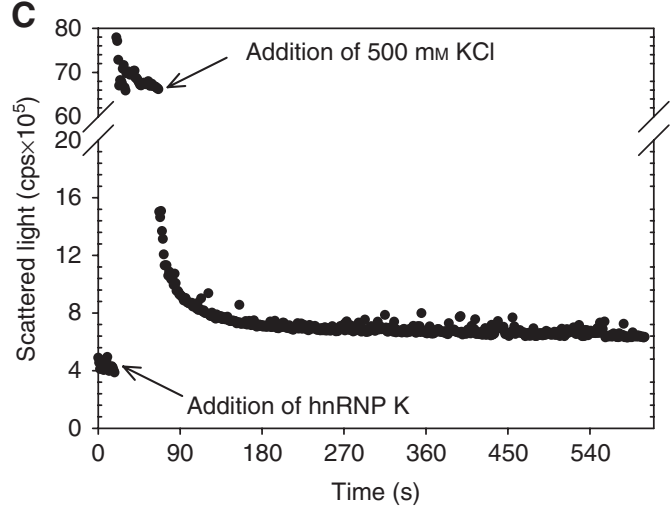

D

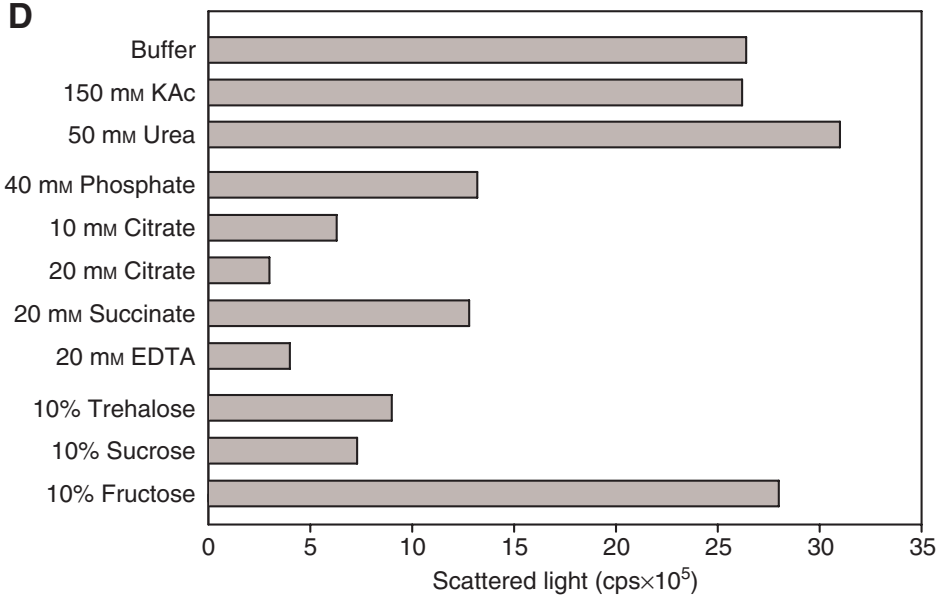

E

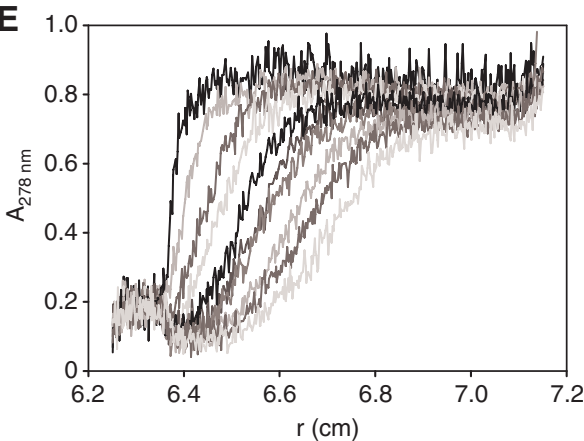

Figure 2 Analysis of reversible hnRNP K aggregation.

(A) Absorption spectra of recombinant non-methylated hnRNP K in $20 \mathrm{~mm}$ Tris $\mathrm{HCl} \mathrm{pH} \mathrm{8.0,10 \%} \mathrm{glycerol} \mathrm{containing} \mathrm{the} \mathrm{KCl}$ concentration indicated. (B) Light-scattering analysis of arginine methylated or non-methylated hnRNP K in $20 \mathrm{~mm}$ TrisHCl pH 8.0, 5\% glycerol. Protein was diluted to $1 \mu \mathrm{M}$ in a stirred glass cuvette in $2 \mathrm{ml}$ with $\mathrm{KCl}$ added to the final concentration indicated. The addition of hnRNP K, which lasted no longer than $6 \mathrm{~s}$ started $45 \mathrm{~s}$ after the start of recording. (C) Light-scattering analysis of non-methylated hnRNP K as in (B) except that the starting buffer contained $50 \mathrm{mM} \mathrm{KCl}$ and was increased to $500 \mathrm{~mm}$ where indicated. (D) Light-scattering analysis of non-methylated hnRNP $\mathrm{K}$ in the presence of the additives indicated was performed as in (B), except that the buffer was $150 \mathrm{~mm} \mathrm{KCl,} 20 \mathrm{~mm} \mathrm{TrisHCl} \mathrm{pH} \mathrm{8.0,}$ $5 \%$ glycerol. The 600 -second data point is plotted. Potassium acetate was substituted for $\mathrm{KCl}$ in an additional experiment, as indicated. (E) Ultracentrifugation of non-methylated hnRNP K in optimized buffer ( $300 \mathrm{~mm} \mathrm{KCl,} 20 \mathrm{~mm} \mathrm{TrisHCl} \mathrm{pH} \mathrm{8.0,50} \mathrm{mm} \mathrm{citric} \mathrm{acid,} 10 \%$ sucrose). Left panel: Sedimentation velocity was plotted every $20 \mathrm{~min}$ at $\lambda=278 \mathrm{~nm}$. The $\mathrm{S}_{20^{\circ} \mathrm{C}}$ of hnRNP K was calculated as 2.3. Right panel: Absorption profile at $\lambda=278 \mathrm{~nm}$ after equilibrium sedimentation for 6 days at $10000 \mathrm{rpm}, 20^{\circ} \mathrm{C}$ and single solute fit. The native molecular weight $\left(M_{\text {apparent }}\right)$ calculated according to Buschmann et al. (2013), see Materials and methods) indicates the presence of monomeric hnRNP K.

The slight preference detected for DNA and the lack of discrimination between DNA and RNA are in agreement with the nucleic acid binding characteristics of isolated $\mathrm{KH} 3$ observed by others (Braddock et al., 2002). The quenching characteristics are well described by the bimolecular association model, but the data could also fit to two sequential 

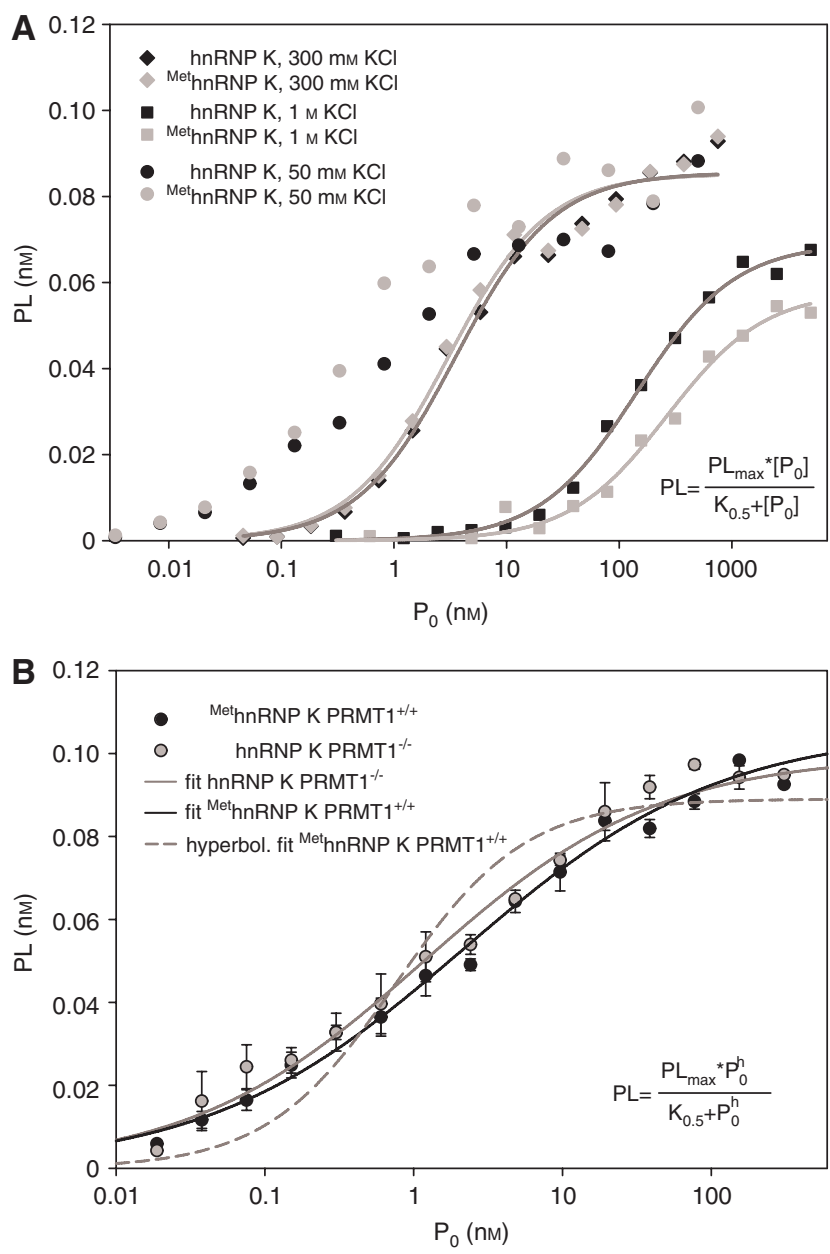

Figure 3 Salt-dependent association of hnRNP K with DICE RNA in filter-binding assays.

(A) Apparent dissociation constants of recombinant hnRNP K or MethnRNP $K$ and [ ${ }^{32} P$ ]-labeled DICE RNA were determined by filter binding experiments as described in the Materials and methods. The complex $(\mathrm{PL})$ is plotted against protein concentration $\left(\mathrm{P}_{0}\right)$. Data were fitted to the equation shown (inset) except for the titration at $50 \mathrm{~mm} \mathrm{KCl}$, which was not fitted. (B) Filter-binding experiments with MethnRNP K or non-methylated hnRNP K purified from ES PRMT1 ${ }^{+/+}$or ES PRMT1\% cells, respectively. Data were fitted to the Hill equation (inset) instead of to a hyperbolic equation (dashed curve).

bindings, with a $\mathrm{K}_{\mathrm{D}}$ of $1 \mathrm{~nm}$ for the first and $30 \mathrm{~nm}$ for the second event (data not shown, Materials and methods). This is relevant in the context of experiments described below.

The repetitive nature of the $\mathrm{C}$ motifs in $2 \mathrm{R}$ might allow binding by more than one hnRNP K molecule, if the first binding event leaves a second site accessible. We followed hnRNP K assembly on a single nucleic acid ligand by intrinsic protein fluorescence. Titrating a $38 \mathrm{nt}$ DNA oligonucleotide (CCCAAA, Table 1) into a $500 \mathrm{~nm}$ hnRNP K solution did not change the intrinsic protein fluorescence (Figure 4B). Thus, the association of hnRNP K with nucleic acids per se does not lead to a change in protein fluorescence. In contrast, when the d2R oligonucleotide with six $\mathrm{C}$ motifs was used, intrinsic fluorescence increased up to a molar ratio of 2:1 hnRNP K:d2R. Further oligonucleotide addition decreased the fluorescence to the original 1:1 ratio (Figure 4B). This can be explained by enhanced intrinsic protein fluorescence due to protein dimerization on the nucleic acid. The maximum signal at a 2:1 molar ratio indicates that two hnRNP $\mathrm{K}$ molecules assemble on one $\mathrm{d} 2 \mathrm{R}$ oligonucleotide. We cannot exclude the possibility that more proteins associate with one $2 \mathrm{R}$ element, but this theory is not supported by the results of the following experiments. The prompt decline in intrinsic fluorescence in the second half of the titration curve suggests that the first binding event is favored over the second. When hnRNP K was titrated into a higher concentration of ${ }^{\mathrm{RNA}} 2 \mathrm{R}$ (125 nM), a biphasic behavior of the binding isotherm was observed (Figure 4C). This could not be discerned in the titration with a lower oligonucleotide concentration (Figure 4A) and clearly deviates from a bimolecular binding mode (Figure 4C). Titration was done at nearly equimolar concentrations, therefore data points were fitted to the exact solution of a sequential binding model (Figure 4C, see Materials and methods). With the first dissociation constant was set to $5 \mathrm{nM}$, the second dissociation constant was calculated as $30 \mathrm{~nm}$. Given the small difference in the two binding events, the two binding motifs are not very different or the second association is favored by cooperativity.

To get more insight into the requirements of the minimal binding motif, we used a competition assay (Figure 5A) based on the detection of hnRNP K associating with ${ }^{\mathrm{RNA}} 2 \mathrm{R}$. An equimolar mixture of $25 \mathrm{nM}$ hnRNP $\mathrm{K}$ and ${ }^{\mathrm{RNA}} 2 \mathrm{R}$ was pre-incubated, and a competing oligonucleotide (Table 1) was subsequently titrated into the solution. The fluorescence signal alteration was fitted to the exact solution of a competition experiment (Wang, 1995), and the $K_{\mathrm{D}}$ for each oligonucleotide was extracted (Figure 5B, $\mathrm{C}$ and $\mathrm{D}$ and Table 1; see Materials and methods). Depending on the affinity of hnRNP K for the different oligonucleotides, the competition was almost complete or only partial. For poorly binding oligonucleotides, the small fraction of competed ${ }^{\mathrm{RNA}} 2 \mathrm{R}$ permits only extrapolation of the $K_{\mathrm{D}}$ values.

From a comparison of the $K_{\mathrm{D}}$ values in Table 1, several conclusions can be drawn. First, $(A)_{38}$ is almost not bound, demonstrating that hnRNP $\mathrm{K}$ has a strong preference to recognize bases and the sugar-phosphate backbone is not sufficient for binding. Second, an $(\mathrm{A})_{34}$ ligand with one 


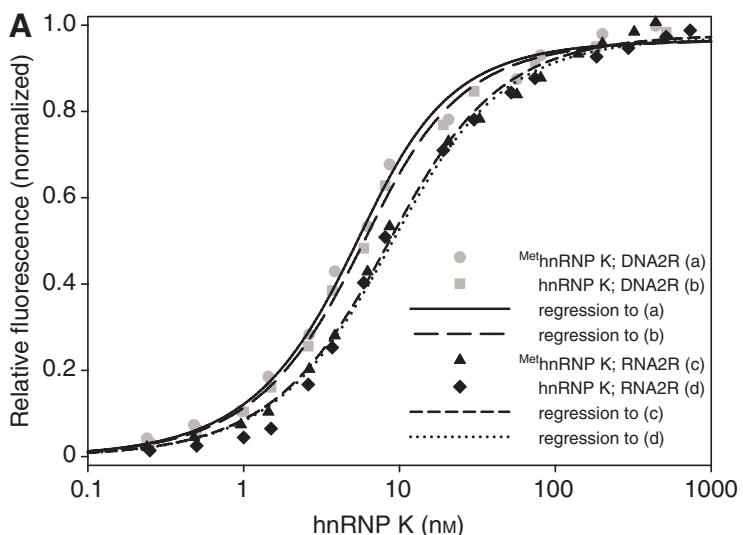

\begin{tabular}{|r|c|c|}
\hline \multicolumn{1}{|c|}{ Protein } & Oligonucleotide & $\mathrm{K}_{\mathrm{D}}+$-sd. (nM) \\
\hline${ }^{\text {MethnRNP K }}$ & DNA 2R & $2.6+/-0.7$ \\
\hline hnRNP K & DNA 2R & $3.1+/-0.7$ \\
\hline${ }^{\text {Met }}$ hnRNP K & RNA 2R & $5.8+/-1$ \\
\hline hnRNP K & RNA 2R & $6.1+/-1$ \\
\hline
\end{tabular}
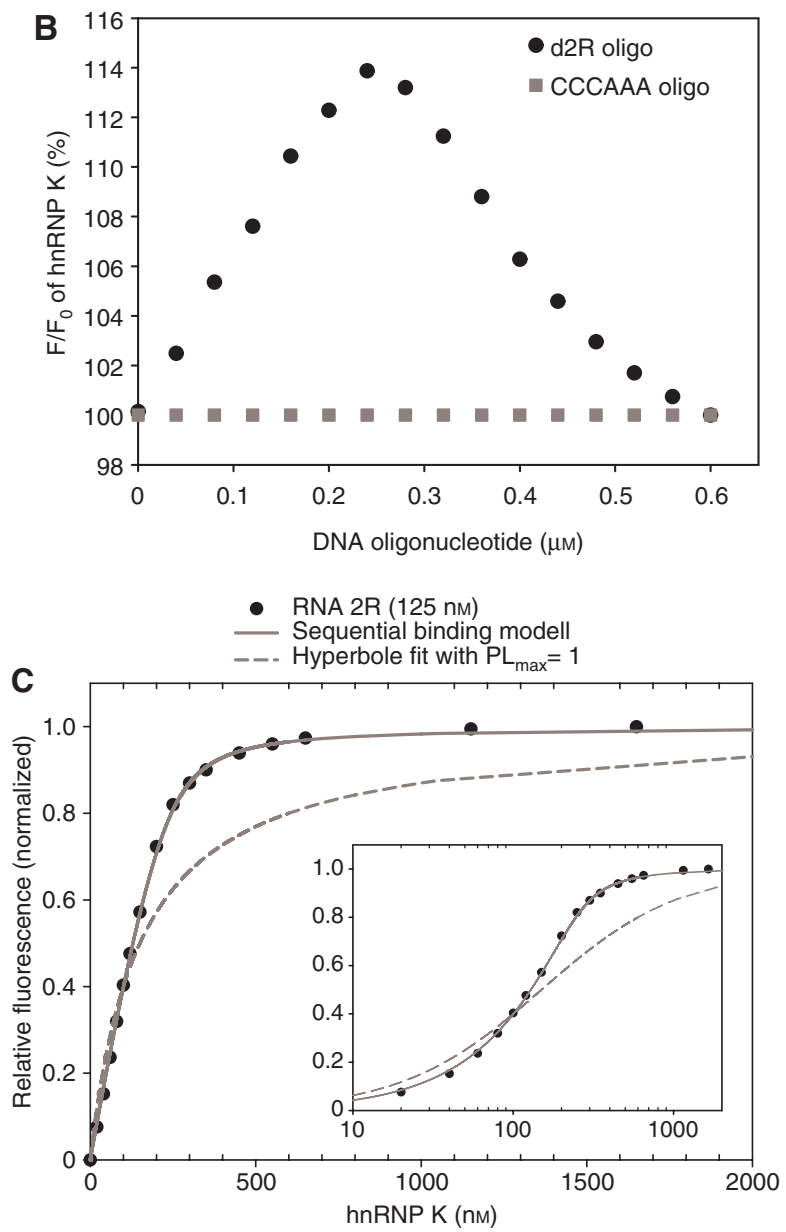

$\mathrm{C}_{4}$ motif is poorly bound, independent of the position of the $\mathrm{C}_{4}$ motif. Finally, the affinity to the ligand increases with the number of $\mathrm{C}_{4}$ motifs.
Figure 4 Binding of recombinant MethnRNP $\mathrm{K}$ and non-methylated hnRNP K to pyrimidine-repeat DNA and RNA oligonucleotides. (A) Association of hnRNP K with fluorescein-labeled desoxy $2 R$ $\left({ }^{\mathrm{DNA}} 2 \mathrm{R}\right)$ or carboxyfluorescein (Fam)-labeled $2 \mathrm{R}\left({ }^{\mathrm{RNA}} 2 \mathrm{R}\right.$ ) oligonucleotides causes fluorescence quenching. HnRNP K variants were titrated into $5 \mathrm{~nm}$ dye-labeled oligonucleotide, and fluorescence alteration was recorded, normalized and plotted against protein concentration. For the determination of dissociation constants, data were fitted to equation 1 (see Materials and methods). (B) The intrinsic protein fluorescence indicates hnRNP K dimerization. Nonfluorescent oligonucleotides $\mathrm{d} 2 \mathrm{R}$ and CCCAAA (Table 1) were titrated into a $500 \mathrm{~nm}$ hnRNP K solution. Intrinsic protein fluorescence was measured and corrected for volume change (see Materials and methods). Relative fluorescence changes were plotted against oligonucleotide concentrations. (C) HnRNP K associates with ${ }^{\mathrm{RNA}} 2 \mathrm{R}$ in a biphasic mode. Fluorescence titration was performed as in (A) except ${ }^{\mathrm{RNA}} 2 \mathrm{R}$ was $125 \mathrm{~nm}$. The data fit to a sequential binding mode shown by the continuous line; a bimolecular association would match the dashed line. Data plotted to logarithmic scale are shown in the inset.

The increase in the affinity of longer homopolymers for a binding protein is predicted to be $K_{\text {app }}=(l-m+1)^{\star} K_{\min }$ by the von Hippel model, where $K_{\text {app }}$ is the association constant of polymer $l, K_{\min }$ the intrinsic binding constant for the minimal ligand $(m), l$ the length of the polymer and $m$ the minimal number of bound nucleotides (Kelly et al., 1976; Mackereth et al., 2011). The empirical relationship between the number of binding sites and affinities is based on the fact that the association is entropically (statistically) favored by multiple binding possibilities (see Supplementary Figure S1). This allows the extraction of the minimal binding motif of a protein by comparison of apparent and predicted affinities (Kelly et al., 1976). The same argument applies to hnRNP K ligands with multiple distinct binding sites such as $\mathrm{C}_{4}$ motifs in an inert poly(A) environment. Here, the affinity of a ligand with one binding site for a protein with one RNA binding domain is expected to increase by a factor of three when two binding sites are added. The increase in affinity for ligands containing two, three, four, five or six $\mathrm{C}_{4}$ motifs compared to one $\mathrm{C}_{4}$ motif is approximately $15,130,750$, 5500 , and 22000 , respectively (Table 1 ). These factors are much higher than predicted for a single domain interaction. This strongly suggests the contribution of more than one domain of hnRNP $\mathrm{K}$ in the binding event.

Assuming a two-domain interaction, two modes of interaction can be envisioned. If the domains are 'restricted' with respect to each other and associate with two adjacent $\mathrm{C}_{4}$ motifs in an obligatory coupled fashion, an affinity increase of three- and five-fold is predicted when the number of $\mathrm{C}_{4}$ motifs is increased from two to four and six. $K_{\mathrm{D}}$ values in Table 1 prove this model false. 
Table 1 Summary of the competition assays, as shown in Figure 5B-D.

\begin{tabular}{|c|c|c|c|c|c|c|}
\hline Name & Sequence & $K_{D}[n M]$ & $\mathbf{R}^{2}$ & Abs. error & $\mathrm{C}_{4}$ motifs & Group mean \\
\hline $\mathrm{m} 2 \mathrm{R}$ & 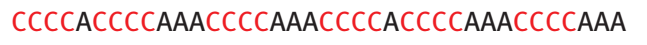 & 1.0 & 0.998 & 0.3 & 6 & \\
\hline $\mathrm{d} 2 \mathrm{R}$ & CCCCGCCCTCTTCCCCAAGCCCCGCCCTCTTCCCCAAG & 2.2 & 0.999 & 0.5 & 6 & \\
\hline CACCCC & CCCCAAAAAAAACCCCAAACCCCACCCCAAACCCCAAA & 3.6 & 0.997 & 1.2 & 5 & 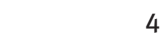 \\
\hline CCCACC & ССССАССССАAАСCCСAAAAAAAACCCCAAACCCCAAA & 4.1 & 0.997 & 1.2 & 5 & \\
\hline CCCCAA & ССССАССССАAАССССАAАССССАAAAAAAAAAAAAAA & 16 & 0.999 & 4 & 4 & 28 \\
\hline CACCAC & 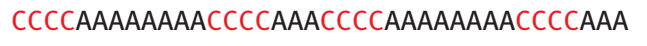 & 24 & 0.998 & 5 & 4 & 28 \\
\hline CCAACC & ССССАССССАAAAAAAAAAAAAAACCCCAAACCCCAAA & 45 & 0.999 & 12 & 4 & 28 \\
\hline CCCAAA & ССССАССССАAАССССАAAAAAAAAAAAAAAAAAAAAA & 108 & 0.994 & 18 & 3 & 168 \\
\hline CACCAA & 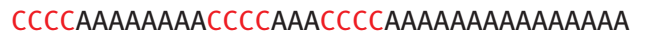 & 102 & 0.994 & 23 & 3 & 168 \\
\hline CCACAA & 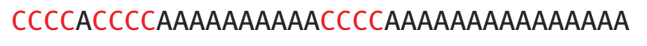 & 122 & 0.994 & 30 & 3 & 168 \\
\hline CCAACA & ССССАССССАAAAAAAAAAAAAAACCCCAAAAAAAAAA & 176 & 0.995 & 42 & 3 & 168 \\
\hline CCAAAC & ССССАССССАAAAAAAAAAAAAAAAAAAAAACCCCAAA & 300 & 0.994 & 60 & 3 & 168 \\
\hline AACACC & AAAAAAAAAAAACCCCAAAAAAAACCCCAAACCCCAAA & 124 & 0.997 & 25 & 3 & 168 \\
\hline ACAACC & AAAAACCCCAAAAAAAAAAAAAAACCCCAAACCCCAAA & 181 & 0.996 & 40 & 3 & 168 \\
\hline CACACA & CCССAAAAAAAACCCCAAAAAAAACCCCAAAAAAAAAA & 231 & 0.992 & 55 & 3 & 168 \\
\hline $\mathrm{CA}_{9} \mathrm{C}$ & AAAAAAAAAACCCCAAAAAAAAACCCCAAAAAAAAAAA & 1590 & 0.993 & 540 & 2 & 1350 \\
\hline $\mathrm{CA}_{7} \mathrm{C}$ & AAAAAAAAAAACCCCAAAAAAACCCCAAAAAAAAAAAA & 1625 & 0.996 & 550 & 2 & 1350 \\
\hline $\mathrm{CA}_{5} \mathrm{C}$ & AAAAAAAAAAAACCCCAAAAACCCCAAAAAAAAAAAAA & 1655 & 0.996 & 550 & 2 & 1350 \\
\hline $\mathrm{CA}_{3} \mathrm{C}$ & 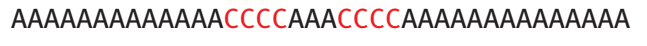 & 1369 & 0.996 & 450 & 2 & 1350 \\
\hline $\mathrm{CA}_{1} \mathrm{C}$ & AAAAAAAAAAAAAACCCСACСCCAAAAAAAAAAAAAAA & 837 & 0.992 & 260 & 2 & 1350 \\
\hline $\mathrm{C}_{8}$ & AAAAAAAAAAAAAAACC CCСCC СAAAAAAAAAAAAAA & 1000 & 0.993 & 420 & 2 & 1350 \\
\hline $\mathrm{C}_{6}^{\circ}$ & AAAAAAAAAAAAAAAACCCCCCAAAAAAAAAAAAAAAA & 5950 & 0.999 & 1500 & 1 & 6000 \\
\hline $\mathrm{C}_{4}$ & AAAAAAAAAAAAAAAAACCCCAAAAAAAAAAAAAAAAA & 36000 & 0.992 & 10000 & 1 & 22200 \\
\hline $\mathrm{C}_{4} \mathrm{~A}_{34}$ & ССССAAAAAAAAAAAAAAAAAAAAAAAAAAAAAAAAAA & 16000 & 0.993 & 4000 & 1 & 22200 \\
\hline $\mathrm{A}_{34} \mathrm{C}_{4}$ & AAAAAAAAAAAAAAAAAAAAAAAAAAAAAAAAAACCCC & 14000 & 0.937 & 8000 & 1 & 22200 \\
\hline$A_{38}$ & AAAAAAAAAAAAAAAAAAAAAAAAAAAAAAAAAAAAAA & 200000 & 0.966 & 200000 & 0 & \\
\hline
\end{tabular}

Names of the oligonucleotides used in the competition assay are listed in the first column, sequences in the second, with cytidine residues marked in red. Competition data were fitted using the analytic solution of a competition experiment (Wang, 1995) and $K_{D}$-values were extracted (column 3). $R^{2}$ is the correlation coefficient of the fits depicted in Figure 5 . The absolute error (Abs. error) error was calculated by combining errors in experiments as well as in concentrations. 'Group average' is the average $K_{\mathrm{D}}$ of all ligands containing the same number of $\mathrm{C}_{4}$ motifs (indicated in bold).

If the domains associate with any two $\mathrm{C}_{4}$ motifs independently, the elevated affinities for ligands containing multiple motifs can be calculated by the laws of combination $(n ! /(n-k) !)$, where $n$ is the number of $\mathrm{C}_{4}$ motifs and $k$ is the number of domains (Supplementary Figure S1). For ligands with two, four and six $\mathrm{C}_{4}$ motifs, the model would predict combinations of $4 ! / 2 !=12$ and $6 ! / 4 !=30$. These numbers have to be divided by the combinations of two domains on two $\mathrm{C}_{4}$ motifs (2!), therefore affinity increases of six-fold and 15 -fold, respectively, are expected. The experimentally observed increases, however, were approximately 50 -fold and 1350-fold. This suggests that this model is not valid either.

A 'restricted' interaction with three domains again predicts an affinity increase of two-, three- and four-fold for an increase in the number of $\mathrm{C}_{4}$ motifs from three to four, five and six. These predicted differences in affinity do not match the observed data (Table 1). On the basis of calculations explained for the two independent domains above, the independent association of three domains with three $\mathrm{C}_{4}$ motifs predicts a four-, ten- and 20-fold affinity increase for ligands with four, five and six $\mathrm{C}_{4}$ motifs. The observed factors six, 40 and 160 do not deviate dramatically but still do not match the theoretical values very well.

Structural studies of the homologous hnRNP E2 show that KH domains 1 and 2 act as one structural unit. The two binding sites on the RNA must be separated by more than five nucleotides ( $\mathrm{Du}$ et al., 2008). Conservation between hnRNP K, hnRNP E1 and hnRNP E2 (Messias et al., 2006) suggests that the same is true for hnRNP K.

To test the affinity of the KH1-KH2 tandem domain and the impact of spacing, we employed the natural occurring caspase-3 cleavage product of hnRNP K (hnRNP $\mathrm{K}_{(1-334)}$ ), which bears $\mathrm{KH} 1$ and $\mathrm{KH} 2$ but lacks KH3 (Naarmann-de Vries et al., 2013) (Supplementary Figure S2). We used again a fluorescence quenching competition assay to elucidate the affinities of DNA ligands with two differentially spaced $\mathrm{C}_{4}$ motifs. The binding of hnRNP $\mathrm{K}_{(1-334)}$ to 19 nts ${ }^{\mathrm{RNA}} \mathrm{CAC}$ (CCC CAA AAA AAA CCC CAA A) was competed poorly with an oligonucleotide containing two $\mathrm{C}_{4}$ motifs 


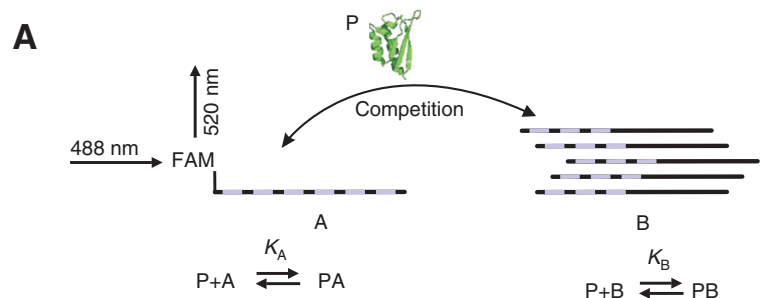

B
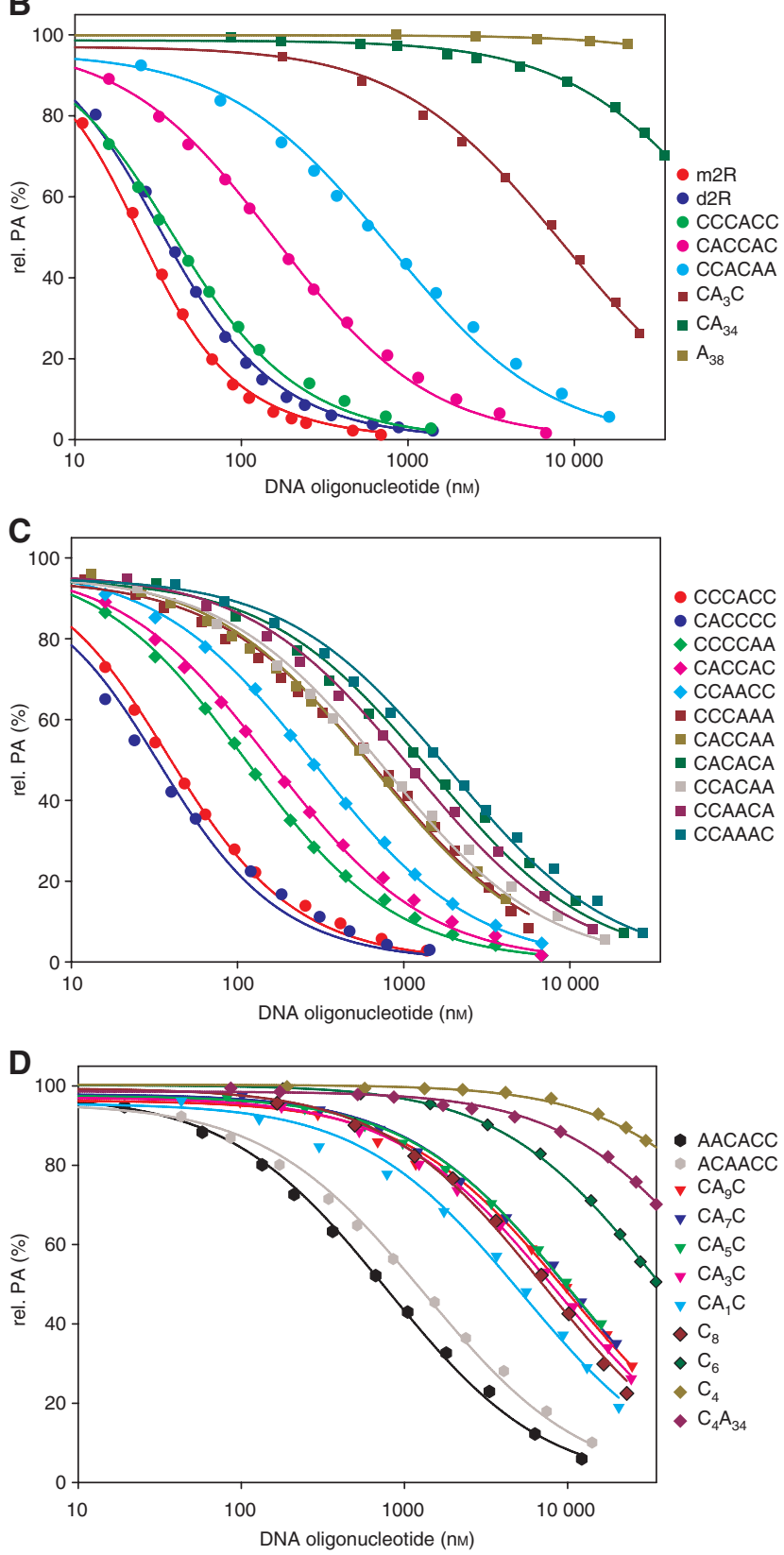

spaced by one nucleotide. Increasing the spacing from five to nine nucleotides revealed improved competition, which declined when the spacing was further extended. This supports the contribution of two interacting domains
Figure 5 Equilibrium association of hnRNP $\mathrm{K}$ with repetitive $\mathrm{C}_{4}$ motifs.

(A) Scheme of the competition assay. Association of hnRNP K with ${ }^{R N A} 2 R$ results in a fluorescence quenching, which is relieved upon addition of competitor that sequesters hnRNP K on non-fluorescent oligonucleotides. (B) Equimolar amounts ( $25 \mathrm{~nm}$ ) of hnRNP K and ${ }^{\mathrm{RNA}} 2 \mathrm{R}$ were pre-incubated in $2 \mathrm{ml}$ buffer $\mathrm{F}$ as in Figure $4 \mathrm{~B}$. Increasing concentrations of the non-fluorescent competing oligonucleotides indicated were added, and changes in fluorescence signal were plotted against the titrated oligonucleotide concentration. Ligands bearing zero to $\mathrm{six}_{4}$ motifs are indicated in the legend and depicted in Table 1. Lines indicate the best fit for a given dataset (Wang, 1995). (C) Competition as in (B) with oligonucleotides containing three, four and five differentially-spaced $\mathrm{C}_{4}$ motifs. (D) Competition as in (B) with oligonucleotides containing one, two and three $\mathrm{C}_{4}$ motifs.

with restriction to an optimal distance of the binding sites in the DNA ligand (Supplementary Figure S2).

The affinity of the KH1-KH2 tandem domain and $\mathrm{KH} 3$ for oligonucleotides containing three $\mathrm{C}_{4}$ motifs was analyzed in filter-binding competition assays (Supplementary Figure S3). In that assay the interaction of hnRNP K with ${ }^{\mathrm{RNA}} 2 \mathrm{R}$ was competed by $\mathrm{d} 2 \mathrm{R}$ with a $K_{\mathrm{D}}$ of $3.2 \mathrm{nM}$, comparable to fluorescence quenching $\left(K_{\mathrm{D}}\right.$ of $2.2 \mathrm{nM}$, Table 1$)$. Besides $\mathrm{d} 2 \mathrm{R}$, a selected number of competitors each bearing three $\mathrm{C}_{4}$ motifs was assessed for competition of hnRNP $\mathrm{K}_{(1-334)}$ and KH3 binding to ${ }^{\mathrm{RNA}} 2 \mathrm{R}$ (Supplementary Figure S3). The affinity of hnRNP $\mathrm{K}_{(1-334)}$ showed a moderate distance dependence for the ligands tested, whereas KH3 did not react differentially to ligands with altered arrangements of $\mathrm{C}_{4}$ motifs (Supplementary Figure $\mathrm{S} 3$ ).

The 170 amino acids separating the $\mathrm{KH} 3$ domain from $\mathrm{KH} 1-\mathrm{KH} 2$ are presumed to be flexible. KH3 is therefore likely to bind independently without spatial restrictions. This predicts a binding mode in which the $\mathrm{KH} 1-\mathrm{KH} 2$ tandem domain can bind to two motifs separated by at least five nucleotides and $\mathrm{KH} 3$ binds to individual motifs.

For a ligand containing tree adjacent $\mathrm{C}_{4}$ motifs (e.g., CCCAAA, Table 1) the likely combinations of hnRNP Ks domains is reduced to two. The resulting quantitative model predicts six-, 18- and 40-fold increased affinities for ligands containing four, five and six $\mathrm{C}_{4}$ motifs as opposed to three $\mathrm{C}_{4}$ motifs (for details, see Materials and methods and Supplementary Figure 1B). The observed factors $(6,40$ and 160) approximate the theoretical calculations reasonably well and slightly better than the model of three independent domains.

In summary, the experimental data are most easily explained by a participation of all three $\mathrm{KH}$ domains in the binding of ligands containing multiple $\mathrm{C}_{4}$ patches, and hence three $\mathrm{C}_{4}$ motifs can be considered the minimal binding motif for hnRNP K. This is consistent with in vitro 
studies showing that recombinant hnRNP E1 (Reimann et al., 2002) and hnRNP K (Ostareck et al., 1997) bind to $1 \mathrm{R}$ (CCC CAC CCU CUU CCC CAA G).

The binding model, referred to hereafter as ' $\mathrm{K}$-combination mode', proposes that: (i) the affinity of a multidomain protein to a ligand increases due to combinatorial interactions if the individual binding sites of the domains are exchangeable; and (ii) the positions of the domains on a nucleic acid can vary due to the independence of the association.

The data in Table 1 also show that hnRNP K can associate with the ligand CCCAAA $\left(K_{\mathrm{D}} 108 \mathrm{nM}\right)$, which contains all its three $\mathrm{C}_{4}$ motifs clustered on one side. This supports the assumption that the association of one hnRNP K molecule with three of the six $\mathrm{C}$ motifs in the $2 \mathrm{R}$ sequence leaves the remaining $\mathrm{C}$ motifs accessible for a second hnRNP K molecule (Figure 4B and C). Direct fluorescence measurement resulted in a $K_{\mathrm{D} 2}$ of the second association of $\sim 30 \mathrm{~nm}$. This small difference (30 $\mathrm{nm}$ versus $108 \mathrm{nM}$ ) provides evidence that the cooperativity between the association of the first and second hnRNP K molecule with the $2 \mathrm{R}$ sequence is low, with a $\Delta \Delta \mathrm{G}^{\prime}$ of $-3.1 \mathrm{~kJ} / \mathrm{mol}$.

\section{Discussion}

\section{Production of methylated hnRNP K}

The recombinant expression of arginine methylated proteins in $E$. coli has previously been reported for two yeast proteins, Sbp1p and Stm1p, which were co-expressed with yeast type I arginine methyltransferase (Hmt1p) (Hsieh et al., 2007). In our hands, a simple co-expression from a bicistronic plasmid did not result in quantitative hnRNP K methylation. We thus modified the method and expressed PRMT1 and hnRNP K from a tricistronic plasmid in a 2:1 ratio. In addition, an extended incubation after inhibition of translation was necessary for complete methylation (Figure 1). All arginine residues previously shown to be quantitatively asymmetrically dimethylated by PRMT1 in vivo (R256, R258, R268, R296 and R299) (Ostareck-Lederer et al., 2006) were detected. The recombinant preparation of methylated hnRNP $\mathrm{K}$ is cheaper and less time-consuming than either purification of the protein from a natural source or in vitro methylation with purified enzymes and SAM. As the method is based on conventional protein expression in E. coli, it can presumably be adapted to other PRMT1 substrates and other PRMTs, if substrate and enzyme are soluble in $E$. coli and sufficiently stable during prolonged incubation in the presence of erythromycin.
The recent development of expressed protein ligation methods enables covalent linkage of chemically synthesized and modified peptides to expressed proteins as an additional alternative to prepare quantitatively methylated protein (Tripsianes et al., 2013).

\section{Reversible aggregation controls protein activity}

Protein aggregation is usually associated with an irreversible loss of function due to unfolding of the protein (Kiefhaber et al., 1991). Aggregation reduces the concentration of active protein and converts the protein solution into an undefined mixture, to which classical mass action analysis cannot be applied. During the preparation of recombinant hnRNP K, it became evident that the protein aggregates in low salt buffer (Figure 2A). The aggregation was reversible, however, and thus probably not related to unfolding (Figure 2B and C). Although aggregation can be suppressed at $1 \mathrm{~m} \mathrm{KCl}$, we analyzed additives that establish more physiological conditions for classical biophysical analyses. Poly-carboxylic acids like citrate and EDTA were quite effective as stabilizers even at low concentrations (10-20 mM) (Figure 2D). These compounds might shield charge differences on the protein surface, a process not fully understood yet. The stabilizing effects of sucrose and trehalose have been studied extensively. They are supposed to arise from increased difference in solubilization energy of the denatured versus the native state due to unfavorable exposure of the peptide backbone to the solvent (Auton et al., 2011). Sucrose therefore forces folding of unstructured parts of the protein, which otherwise would be prone to aggregation (Baskakov and Bolen, 1998). Under optimized buffer conditions, hnRNP K is monodisperse and sediments as a monomer in analytical ultracentrifugation (Figure 2E).

\section{RNA interaction of hnRNP K}

MethnRNP K and non-methylated hnRNP K either expressed as recombinant proteins or purified from $\mathrm{PRMT1}^{+++}$or PRMT1 $^{-1}$ ES cells did not show differences in DICE binding (Figure $3 \mathrm{~A}$ and $\mathrm{B}$ ) or binding to a ${ }^{\mathrm{RNA}} 2 \mathrm{R}$ oligonucleotide (Figure 4A), which was consistent with earlier observations (Ostareck-Lederer et al., 2006). To study the mechanism of RNA binding by hnRNP K in vitro, non-methylated hnRNP K was analyzed.

The high affinity of hnRNP K for C-rich oligonucleotides depends on the presence of multiple $\mathrm{C}$ motifs, which 
serve as KH domain binding sites. The very low affinity of hnRNP $\mathrm{K}$ for poly(A) suggests that at least adenines are excluded from recognition motifs. A sequential evolution of ligands by exponential enrichment study with hnRNP $\mathrm{K}$ resulted in the selection of strongly folded oligonucleotides that contained only one $\mathrm{C}$ motif in single-stranded loops. The affinity of hnRNP $\mathrm{K}$ was estimated to be $\sim 50 \mathrm{~nm}$ (Thisted et al., 2001). This affinity is lower than that of the ligands that bear multiple $\mathrm{C}_{4}$ motifs, but higher than that of ligands with a single $\mathrm{C}_{4}$ motif in an unstructured environment (Table 1). Thus, it is possible that hnRNP K can bind nucleic acid ligands in different modes. The data from the competition assay show the complex nature of single-stranded RNA high-affinity binding.

The ' $K$-combination mode' provides a model for interpreting multivalent protein ligand interactions, but still is an oversimplification that neglects the motif spacing and steric hindrance of the domains. Due to the flexible nature of RNA, independent RNA association of multiple domains may be supported by appropriate RNA folding. The conservation of KH1 and KH2 between hnRNP K, hnRNP E1 and hnRNP E2 suggest that they function as a tandem domain (Du et al., 2008). The RNA-binding surfaces of the KH1-KH2 tandem domain require the two binding motifs in the nucleic acid to be separated by more than five nucleotides (Du et al., 2008). To further verify the participation of all tree $\mathrm{KH}$-domains in ligand binding, we determined the sedimentation velocity of hnRNP K in complex with either a 19 nt DNA ligand containing two (CAC) or three $\mathrm{C}_{4}$ motifs (CCC) (Supplementary Figure 4). The apparent S-value of hnRNP K alone was $\sim 2.3$, and in complex with CAC the approximate S-value was $\sim 2.5$. Surprisingly the hnRNP K and CCC complex sedimented at $\sim 3.4 \mathrm{~S}$, but also in heavy complexes at $\sim 10.5 \mathrm{~S}$. Using equilibrium sedimentation we were unable to prove that the $2.5 \mathrm{~S}$ and $3.4 \mathrm{~S}$ complexes had the same mass due to the instability of the $3.4 \mathrm{~S}$ complex (Supplementary. Figure 4). Given the small change in the S-value of hnRNP K compared to the mixture of hnRNP K and CAC, the increased S-value of hnRNP K and CCC possibly results from a change in conformation rather than stoichiometry.

In ultraviolet-crosslinking studies employing isolated domains (KH1, KH2 and KH3) of hnRNP K, only KH3 did bind to the 190 nts DICE RNA (Messias et al., 2006). Structural analyses revealed a stoichiometry for $\mathrm{KH} 3$ and $1 \mathrm{R}$ (CCC CAC CCU CUU CCC CAA G) of 2:1 and for the (UCC CCA A) 1R fragment of 1:1 (Backe et al., 2005). The isolated KH3 domain has a micromolar affinity for the $1 \mathrm{R}$ fragment (Backe et al., 2005). In contrast, full-length hnRNP $\mathrm{K}$ binds a nucleic acid ligand containing three $\mathrm{C}_{4}$ motifs with an affinity of $\sim 100 \mathrm{~nm}$ (Table 1). As KH3 is separated from KH1-KH2 by a flexible linker of 170 amino acids, the considerations of Shamoo et al. (1995) suggest that the KH1-KH2 tandem domain has a higher affinity for a nucleic acid ligand containing two $\mathrm{C}_{4}$ motifs than the $\mathrm{KH} 3$ domain for an isolated $\mathrm{C}_{4}$ motif. This conclusion is supported by yeast three hybrid data with individual and combined hnRNP K KH domains, which showed stronger binding of the $\mathrm{KH} 1-\mathrm{KH} 2$ tandem domain compared to individual $\mathrm{KH}$ domains (Klimek-Tomczak et al., 2004). Comparing in vitro DICE binding of isolated $\mathrm{KH} 3$ and the $\mathrm{KH} 1-\mathrm{KH} 2$ tandem domain revealed specific binding of $\mathrm{KH} 3$, whereas the $\mathrm{KH} 1-\mathrm{KH} 2$ tandem domain exhibited weak DICE binding and non-specific interaction with control RNA (Naarmann-de Vries et al., 2013).

The determination of equilibrium affinities of hnRNP $\mathrm{K}$ for different ligands in vitro permits a direct view on the sequence-dependent association of the protein with RNA. However, in the context of cellular hnRNP $\mathrm{K}$ interactions, which are modulated by post-translational modifications and components in dynamic mRNPs, functional validation of sequence specificity and individual domain contribution is required (Ostareck-Lederer et al., 2002, 2006; Adolph et al., 2007; Ostareck-Lederer and Ostareck, 2012; Naarmann-de Vries et al., 2013). The specificity of KH3 binding is supported by loss of hnRNP K DICE binding following phosphorylation of KH3 Y458 (Messias et al., 2006). Tyrosine phosphorylation abrogates hnRNP $\mathrm{K}$ dependent translation regulation in vitro (Messias et al., 2006) and in vivo (Ostareck-Lederer et al., 2002). Finally, $1 R$ with three $C$ motifs is required for hnRNP $\mathrm{K}$ binding, but $2 \mathrm{R}$ is necessary and sufficient for translation repression (Ostareck et al., 1997), which is in agreement with the ' $K$-combination mode' of RNA binding.

\section{Materials and methods}

\section{Plasmids}

The coding region of hnRNP K (GenBank:AAB20770.1; Ostareck et al., 1997) was polymerase chain reaction (PCR)-amplified with primers $\# 1$ and \#2 to introduce NheI and XhoI restriction sites and cloned into pet28 (Novagene, Darmstadt, Germany). The tricistronic expression construct was cloned sequentially based on pET28b-PRMT1 (Zhang and Cheng, 2003; a kind gift from X. Cheng). The plasmid was used to amplify the ribosome-binding site and PRMT1 coding region and to insert a XhoI site at either end with primers \#3 and \#4. The PCRproduct was cloned into XhoI of pET28b-PRMT1 to generate a bicistronic PRMT1 expression plasmid. The ribosome binding site, His-tag coding sequence and coding region of hnRNP $\mathrm{K}$ was amplified from pet28-His-hnRNP K with primers \#5 and \#6, and the PCR-product was cloned in the SalI site of the bicistronic PRMT1 plasmid to generate the tricistronic T7-expression construct (pET-PKP). All plasmids were verified by sequencing. The primers are listed in Table 2 . 


\section{Protein expression and purification}

E. coli expression for experiments shown in Figure 1A-C and lysis were performed as described in Moritz and Wahle (2014), except induction was for $4 \mathrm{~h}$ at $22^{\circ} \mathrm{C}$. Preparation of hnRNP $\mathrm{K}$ for all of the following experiments was performed under fermentation conditions at $37^{\circ} \mathrm{C}$ in $61 \mathrm{M} 9$ minimal medium supplemented with glucose $(0.4 \% \mathrm{w} / \mathrm{v})$, thiamine $(1 \mathrm{mg} / \mathrm{l})$, biotin $(3 \mathrm{mg} / \mathrm{l})$, kanamycin $(30 \mathrm{mg} / \mathrm{l})$ and micronutrients SL-4 and SL-6 (Pfennig and Lippert, 1966). At $\mathrm{OD}_{600 \mathrm{~nm}}=2$ the culture was continuously fed with glucose $(10 \% \mathrm{w} / \mathrm{v})$ and $\mathrm{NH}_{4} \mathrm{Cl}(10 \% \mathrm{w} / \mathrm{v})$. At $\mathrm{OD}_{600 \mathrm{~nm}}=30$ the culture was cooled to $20^{\circ} \mathrm{C}$, and expression was induced for $4 \mathrm{~h}$ with $0.5 \mathrm{~mm}$ isopropyl $\beta$-D-1thiogalactopyranoside. Erythromycin $(30 \mathrm{mg} / \mathrm{l})$ was added and fermentation continued for $2 \mathrm{~h}$. Cells were harvested by centrifugation (30 min, $4000 \mathrm{~g}, 4^{\circ} \mathrm{C}$ ).

E. coli lysates containing hnRNP K were cleared by centrifugation $\left(1 \mathrm{~h}, 30000 \mathrm{~g}, 4^{\circ} \mathrm{C}\right)$, applied to a $5 \mathrm{ml} \mathrm{Ni}$-nitrilotriacetic acid column (Qiagen, Hilden, Germany) and washed with lysis buffer [600 mM KCl, 20 mM Tris- $\mathrm{HCl} \mathrm{pH}$ 8.0, 20 mm imidazole, $3 \mathrm{~mm} \mathrm{MgCl}$, $10 \%(\mathrm{w} / \mathrm{v})$ glycerol] adjusted to $1 \mathrm{~m} \mathrm{KCl}$ until the column eluate had $\mathrm{A}_{280 \mathrm{~nm}} \leq 0.4$. Proteins were eluted with a linear imidazole gradient to $500 \mathrm{~mm}$ in lysis buffer $(30 \mathrm{ml})$. HnRNP K-containing fractions were identified by Coomassie staining. They were pooled and immediately loaded onto a $10 \mathrm{ml}$ hydroxyapatite column (Biorad, Munich, Germany) equilibrated in buffer A (300 mM KCl, $20 \mathrm{~mm}$ imidazole $\mathrm{pH}$ 8.0, $10 \%$ (w/v) sucrose). Bound hnRNP K was eluted with a linear potassium phosphate gradient in buffer A (up to $100 \mathrm{~mm} \mathrm{~K}_{3} \mathrm{PO}_{4}$ in a $50 \mathrm{ml}$ gradient). Pooled hnRNP K fractions were diluted drop-wise into 20 $\mathrm{mm}$ TrisHCl pH 8.0, $10 \%$ (w/v) sucrose to a conductivity of $\leq 10 \mathrm{mS} /$ $\mathrm{cm}\left(15^{\circ} \mathrm{C}\right)$ and immediately loaded onto a $5 \mathrm{ml}$ MonoQ column (GE Healthcare, Solingen, Germany) equilibrated in buffer B (150 mM $\mathrm{KCl}, 20 \mathrm{~mm}$ TrisHCl pH8.0, 10\% (w/v) sucrose). A linear gradient of 35-500 mM KCl (buffer B) eluted bound hnRNP K. HnRNP K concentration was determined by measuring the absorbance at $\lambda=280 \mathrm{~nm}$ using an extinction coefficient of $39430 \mathrm{M}^{-1} \mathrm{~cm}^{-1}$.

\section{ES cell extract fractionation}

Murine embryonic stem cells (ES) PRMT1 ${ }^{+/+}$and ES PRMT1 ${ }^{-/}$cells (Pawlak et al., 2000) were cultured as described (OstareckLederer et al., 2006), and extract was prepared as in Fronz et al. (2008). To achieve efficient elimination of nucleic acids

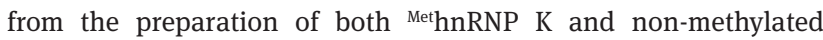
hnRNP K, which were purified for RNA- and DNA-binding experiments, the procedure included four subsequent chromatography steps as follows: $100 \mathrm{ml}$ lysate was dialyzed against buffer C2

Table 2 Primers used in polymerase chain reaction amplification.

\begin{tabular}{cl}
\hline Primer \# & 5' sequence \\
\hline 1 & aaaGCTAGCGAAACTGAACAGCCAGAAG \\
2 & aaaCTCGAGTTAGAATCCTTCAACATCTG \\
3 & aaaCTCGAGAACTTTAAGAAGGAGATATACCATG \\
4 & TTTCTCGAGTTCAGCGCATCCGGTAGTCGG \\
5 & ttGTCGACAACTTTAAGAAGGAGATATACCATG \\
6 & ttGTCGACCCGGATCATCAGTGGTG \\
\hline
\end{tabular}

(50 mm KCl, 50 mm TrisHCl pH 7.4, 1 mm EDTA, 1 mm dithiothreitol (DTT), 10\% glycerol) and centrifuged (1 h, $20000 \mathrm{~g})$, and the supernatant (2 g total protein) was loaded onto a DEAE-Sepharose fast flow column (150 ml; GE Healthcare, Solingen, Germany) equilibrated in buffer $\mathrm{C} 2$. Proteins were eluted with a linear $\mathrm{KCl}$ gradient (1.5 l) to $500 \mathrm{~mm}$. Fractions containing hnRNP K were pooled, dialyzed against buffer D (50 mm KCl, 50 mm HEPES pH 7.4, 1 mm EDTA, $1 \mathrm{~mm}$ DTT, $10 \%$ glycerol), and applied to a Macroprep-S column (50 $\mathrm{ml}$; GE Healthcare, Solingen, Germany). Proteins were eluted by a linear gradient $(500 \mathrm{ml}$ ) to $500 \mathrm{~mm} \mathrm{KCl}$. Pooled hnRNP K containing fractions were dialyzed against buffer $\mathrm{E}(100 \mathrm{mM} \mathrm{KCl,} 20 \mathrm{mM}$ imidazole $\mathrm{pH}$ 7.2, 1 mM MgCl, 1 mM DTT, 10\% glycerol) and applied to a hydroxyapatite column ( $25 \mathrm{ml}$; Biorad, Munich, Germany). The column was washed with three volumes buffer $\mathrm{E}$, and proteins were eluted by a shallow gradient $(70 \mathrm{ml})$ to $100 \mathrm{~mm}$ potassium phosphate $\mathrm{pH} 7.4$ followed by a steep gradient $(10 \mathrm{ml})$ to $500 \mathrm{~mm}$ potassium phosphate in buffer E. HnRNP K-containing fractions were pooled, dialyzed against buffer F1 (100 mm KCl, 20 mm TrisHCl pH 7.4, 1 mM DTT, 10\% glycerol) and applied to a Blue-Sepharose column (1 ml; GE Healthcare, Solingen, Germany). Proteins were eluted by a gradient $(12 \mathrm{ml})$ to $2.5 \mathrm{M} \mathrm{KCl}$ in buffer F1. The concentration of hnRNP K in pooled fractions was estimated by Coomassie staining calibrated with recombinant hnRNP K.

\section{Light scattering and fluorescence experiments}

Analysis of protein aggregation was performed on a Fluoromax-4 spectrofluorometer (Horiba, Jobin Yvon, France). For light-scattering experiments at $\lambda=320 \mathrm{~nm}$ (slit width $2 \mathrm{~nm}), 50 \mu \mathrm{l}$ of hnRNP K $(70 \mu \mathrm{M})$ in $1 \mathrm{M} \mathrm{KCl}, 20 \mathrm{~mm}$ TrisHCl pH 8.0, 10\% glycerol was diluted into $2 \mathrm{ml}$ of the buffer indicated and scattered light [cps] was measured over time.

Intrinsic fluorescence was measured in buffer F2 $(300 \mathrm{~mm}$ potassium chloride, $20 \mathrm{~mm}$ TrisHCl pH 8.0, $10 \%$ sucrose, $1 \mathrm{~mm} \mathrm{DTT}$ ) at $20^{\circ} \mathrm{C}$ with excitation at $\lambda=295 \mathrm{~nm}$ and emission at $\lambda=355 \mathrm{~nm}$ and slit widths of $2 \mathrm{~nm}$ and $3 \mathrm{~nm}$. Continuous fluorescence of a $2.5 \mathrm{ml}$ stirred $500 \mathrm{nM}$ hnRNP K solution was recorded while the oligonucleotide indicated was titrated. Total fluorescence was corrected for volume change. Inner filter effect was smaller than $2 \%$ at the highest oligonucleotide concentration. Relative fluorescence to a buffer control titration was plotted against oligonucleotide titration.

Fluorescence of oligonucleotides ${ }^{\mathrm{DNA}} 2 \mathrm{R}$ and ${ }^{\mathrm{RNA}} 2 \mathrm{R}$ was measured (excitation at $\lambda=488 \mathrm{~nm}$, emission at $\lambda=518 \mathrm{~nm}$; slit widths $1-4 \mathrm{~nm}$ and 2-4 nm) in buffer F2 including $20 \mathrm{U} / \mathrm{ml}$ ribolock (Fermentas, Vilnius, Lithuania) and $15 \mu \mathrm{g} / \mathrm{ml}$ His-SUMO protein as competitor to reduce surface adsorption and was corrected for volume change and dynamic quenching. Relative fluorescence was plotted against the analyte concentration. Bimolecular equilibrium dissociation constants $\left(\mathrm{K}_{\mathrm{D}}\right)$ were derived by fitting the data points with SigmaPlot ${ }^{\circledR}$ (SPSS Inc.) to equation 1 :

$$
\Delta F=\frac{\Delta F_{\max }}{L_{0}} \star\left[\frac{\left(K_{\mathrm{D}}+P_{0}+L_{0}\right)}{2}-\sqrt{\frac{\left(K_{\mathrm{D}}+P_{0}+L_{0}\right)^{2}}{4}-P_{0}{ }^{\star} L_{0}}\right]
$$

were $P_{0}=$ hnRNP K and $L_{0}=$ oligonucleotide concentration.

Extraction of the second equilibrium dissociation constant $\mathrm{K}_{\mathrm{D} 2}$ according to the sequential association/dissociation reaction: 


$$
L+P \stackrel{K_{D 1}}{\longleftrightarrow} Q+P \stackrel{K_{D 2}}{\longleftrightarrow} R
$$

led to $K_{D 1}=\frac{L^{\star} P}{Q} ; \quad K_{D 2}=\frac{Q^{\star} P}{R}$

which was achieved by converting mass action laws to the third power equation 2 (Spinka and Moritz, unpublished).

$$
\begin{aligned}
& 0=P^{3}+\left(2^{\star} L_{0}-P_{0}+K_{D 2}\right){ }^{\star} P^{2}+\left(K_{D 2}{ }^{\star} \alpha+K_{D 1}{ }^{\star} K_{D 2}\right){ }^{\star} P-K_{D 1}{ }^{\star} K_{D 2}{ }^{\star} P_{0} \\
& \alpha=L_{0}-P_{0}
\end{aligned}
$$

and fitting the data to the two alternate physically meaningful solutions to equation 2.

For competition experiments, the relative fluorescence of ${ }^{\mathrm{RNA}} 2 \mathrm{R}$ was plotted against the competitor concentration. Data points were fitted with SigmaPlot ${ }^{\circledR}$ (SYSTAT GmbH, Erkrath, Germany) using the exact solution of a simple competition (Wang, 1995):

$$
[P B]=\frac{[P]\left[B_{0}\right]}{K_{B}+[P]} ;[P A]=\frac{[P]\left[A_{0}\right]}{K_{A}+[P]}
$$

where $\mathrm{P}$ is hnRNP $\mathrm{K}, \mathrm{A}$ is ${ }^{\mathrm{RNA}} 2 \mathrm{R}, \mathrm{B}$ is the competitor oligonucleotide, $\mathrm{PB}$ is the non-fluorescent hnRNP $\mathrm{K}$-competitor complex and PA the hnRNP K-RNA2R complex.

Calculations of affinity increases avoiding $\mathrm{KH} 1-\mathrm{KH} 2$ on adjacent $\mathrm{C}_{4}$ motifs were as follows. Combination of three domains on four $\mathrm{C}_{4}$ motifs=4!/1! subtracted by 12 forbidden combinations due to space limitations $=12$ divided by two allowed combinations of three domains on tree adjacent $\mathrm{C}_{4}$ motifs $=6$. Combination of three domains on five $C_{4}$ motifs $=(5 ! / 2 !-24) / 2=18$. Combination of three domains on six $\mathrm{C}_{4}$ motifs $=(6 ! / 3 !-40) / 2=40$.

\section{Filter-binding assays}

Filter-binding experiments were performed on nitrocellulose membrane as described in Kuhn et al. (2003) and Wahle et al. (1993) with DICE RNA prepared according to Ostareck et al. (1997). Data points were either fitted to a simple hyperbole equation or a Hill equation given in the inset of the corresponding graphs, where $\mathrm{P}_{0}$ is the total protein concentration, $\mathrm{PL}$ the signal for the complex and $\mathrm{K}_{0.5}$ the concentration at half of the maximal signal $\left(\mathrm{PL}_{\max }\right)$ (Figure $3 \mathrm{~A}$ and $3 \mathrm{~B}$ ).

\section{Mass spectrometry analysis}

Peptides of methylated hnRNP K were generated and analyzed by capillary high-performance liquid chormatography-coupled electrospray ionization quadrupole time of flight mass-spectrometry (Ultima Waters, Milford, MA, USA) as described (Naarmann et al., 2010; Naarmann-de Vries et al., 2013). Peptide assignments and data analysis were performed by Mascot ${ }^{\circledR}$ (Matrix Science, London, UK).

\section{Analytical ultracentrifugation}

Ultracentrifugation was carried out as described in Buschmann et al. (2013) with minor modifications. HnRNP K was dialyzed against $300 \mathrm{~mm} \mathrm{KCl,}, 20 \mathrm{~mm}$ TrisHCl pH 8.0, $50 \mathrm{~mm}$ potassium citrate and 10\% sucrose. Velocity sedimentation was performed at $40000 \mathrm{rpm} 20^{\circ} \mathrm{C}$.
Equilibrium sedimentation was carried out at $10000 \mathrm{rpm}$ at $20^{\circ} \mathrm{C}$ for 6 days. All sedimentation data were analyzed using Sedfit software (National Institutes of Health, Bethesda, MD, USA) (Schuck, 2000).

\section{Methylation assays}

Protein arginine methylation was determined by analysis of $\left[{ }^{14} \mathrm{C}\right]-$ methyl group incorporation as described (Ostareck-Lederer et al., 2006; Fronz et al., 2008), or by Western blot assays with methylationspecific antibodies (Naarmann et al., 2008; Gross et al., 2012).

Acknowledgments: We are grateful to Michael Spinka for critical discussions on association equilibria and advice on SigmaPlot ${ }^{\circledR}$ analysis. Special thanks to all members of the GRK 1026 for critical discussions and advice. We acknowledge X. Cheng for providing pET28b-PRMT1. We thank Nadine Simons for technical assistance. Funding was provided by the DFG to D.H.O. (GRK 1026); to A.O.-L. (OS 290/1-1, 1-2 and OS 290/2-1, 2-2); and to E.W. (SFB 610).

\section{References}

Adolph, D., Flach, N., Mueller, K., Ostareck, D.H., and OstareckLederer, A. (2007). Deciphering the cross talk between hnRNP $\mathrm{K}$ and c-Src: the c-Src activation domain in hnRNP $\mathrm{K}$ is distinct from a second interaction site. Mol. Cell Biol. 27, 1758-1770.

Auton, M., Rosgen, J., Sinev, M., Holthauzen, L.M., and Bolen, D.W. (2011). Osmolyte effects on protein stability and solubility: a balancing act between backbone and side-chains. Biophys. Chem. 159, 90-99.

Baber, J.L., Libutti, D., Levens, D., and Tjandra, N. (1999). High precision solution structure of the $\mathrm{C}$-terminal $\mathrm{KH}$ domain of heterogeneous nuclear ribonucleoprotein $\mathrm{K}$, a c-myc transcription factor. J. Mol. Biol. 289, 949-962.

Backe, P.H., Messias, A.C., Ravelli, R.B., Sattler, M., and Cusack, S. (2005). X-ray crystallographic and NMR studies of the third KH domain of hnRNP K in complex with single-stranded nucleic acids. Structure 13, 1055-1067.

Baskakov, I. and Bolen, D.W. (1998). Forcing thermodynamically unfolded proteins to fold. J Biol. Chem. 273, 4831-4834.

Bedford, M.T. and Clarke, S.G. (2009). Protein arginine methylation in mammals: who, what, and why. Mol. Cell 33,1-13.

Bedford, M.T. and Richard, S. (2005). Arginine methylation an emerging regulator of protein function. Mol Cell 18, 263-272.

Bomsztyk, K., Denisenko, O., and Ostrowski, J. (2004). hnRNP K: one protein multiple processes. Bioessays 26, 629-638.

Braddock, D.T., Baber, J.L., Levens, D., and Clore, G.M. (2002). Molecular basis of sequence-specific single-stranded DNA recognition by KH domains: solution structure of a complex between hnRNP K KH3 and single-stranded DNA. EMBO J. 21, 3476-3485.

Buschmann, J., Moritz, B., Jeske, M., Lilie, H., Schierhorn, A., and Wahle, E. (2013). Identification of Drosophila and human 7-methyl GMP-specific nucleotidases. J. Biol. Chem. 288, 2441-2451. 
Chan, J.Y., Hsieh, T.Y., Liu, S.T., Chou, W.Y., Chung, M.H., and Huang, S.M. (2009). Physical and functional interactions between hnRNP K and PRMT family proteins. FEBS Lett. 583, 281-286.

Chen, Y., Zhou, X., Liu, N., Wang, C., Zhang, L., Mo, W., and Hu, G. (2008). Arginine methylation of hnRNP K enhances $p 53$ transcriptional activity. FEBS Lett. 582, 1761-1765.

Chiou, Y.Y., Lin, W.J., Fu, S.L., and Lin, C.H. (2007). Direct massspectrometric identification of Arg296 and Arg299 as the methylation sites of hnRNP K protein for methyltransferase PRMT1. Protein J. 26, 87-93.

Clery, A., Blatter, M., and Allain, F.H. (2008). RNA recognition motifs: boring? Not quite. Curr. Opin. Struct. Biol. 18, 290-298.

Dejgaard, K. and Leffers, H. (1996). Characterisation of the nucleic-acid-binding activity of $\mathrm{KH}$ domains. Different properties of different domains. Eur. J. Biochem. 241, 425-431.

Du, Z., Fenn, S., Tjhen, R., and James, T.L. (2008). Structure of a construct of a human poly(C)-binding protein containing the first and second $\mathrm{KH}$ domains reveals insights into its regulatory mechanisms. J. Biol. Chem. 283, 28757-28766.

Duquette, M.L., Pham, P., Goodman, M.F., and Maizels, N. (2005). AID binds to transcription-induced structures in c-MYC that map to regions associated with translocation and hypermutation. Oncogene 24, 5791-5798.

Evans, J.R., Mitchell, S.A., Spriggs, K.A., Ostrowski, J., Bomsztyk, K., Ostarek, D., and Willis, A.E. (2003). Members of the poly ( $\mathrm{rC}$ ) binding protein family stimulate the activity of the c-myc internal ribosome entry segment in vitro and in vivo. Oncogene $22,8012-8020$.

Fronz, K., Otto, S., Kolbel, K., Kuhn, U., Friedrich, H., Schierhorn, A., Beck-Sickinger, A.G., Ostareck-Lederer, A., and Wahle, E. (2008). Promiscuous modification of the nuclear poly(A)-binding protein by multiple protein-arginine methyltransferases does not affect the aggregation behavior. J. Biol. Chem. 283, 20408-20420.

Gary, J.D. and Clarke, S. (1998). RNA and protein interactions modulated by protein arginine methylation. Prog. Nucleic Acid Res. Mol. Biol. 61, 65-131.

Gibson, T.J., Thompson, J.D., and Heringa, J. (1993). The KH domain occurs in a diverse set of RNA-binding proteins that include the antiterminator NusA and is probably involved in binding to nucleic acid. FEBS Lett. 324, 361-366.

Ginno, P.A., Lott, P.L., Christensen, H.C., Korf, I., and Chedin, F. (2012). R-loop formation is a distinctive characteristic of unmethylated human $\mathrm{CpG}$ island promoters. Mol. Cell 45, 814-825.

Grishin, N.V. (2001). KH domain: one motif, two folds. Nucleic Acids Res. 29, 638-643.

Gross, H., Hennard, C., Masouris, I., Cassel, C., Barth, S., StoberGrasser, U., Mamiani, A., Moritz, B., Ostareck, D., OstareckLederer, A., et al. (2012). Binding of the heterogeneous ribonucleoprotein K (hnRNP K) to the Epstein-Barr virus nuclear antigen 2 (EBNA2) enhances viral LMP2A expression. PLoS One 7, e42106.

Hsieh, C.H., Huang, S.Y., Wu, Y.C., Liu, L.F., Han, C.C., Liu, Y.C., and Tam, M.F. (2007). Expression of proteins with dimethylarginines in Escherichia coli for protein-protein interaction studies. Protein Sci. 16, 919-928.

Huang, H.M., Tam, M.F., Tam, T.C., Chen, D.H., Hsieh, M., and Li, C. (2002). Proteomic analysis of stable protein methylation in lymphoblastoid cells. J. Biochem. 132, 813-818.
Huarte, M., Guttman, M., Feldser, D., Garber, M., Koziol, M.J., Kenzelmann-Broz, D., Khalil, A.M., Zuk, O., Amit, I., Rabani, M., et al. (2010). A large intergenic noncoding RNA induced by p53 mediates global gene repression in the $\mathrm{p} 53$ response. Cell 142, 409-419.

Kanno, H., Onodera, H., Endo, M., Maeda, F., Chida, S., Akasaka, T., and Sawai, T. (2005). Vascular lesion in a patient of chronic active Epstein-Barr virus infection with hypersensitivity to mosquito bites: vasculitis induced by mosquito bite with the infiltration of nonneoplastic Epstein-Barr virus-positive cells and subsequent development of natural killer/T-cell lymphoma with angiodestruction. Hum. Pathol. 36, 212-218.

Kelly, R.C., Jensen, D.E., and von Hippel, P.H. (1976). DNA “melting” proteins. IV. Fluorescence measurements of binding parameters for bacteriophage T4 gene 32-protein to mono-, oligo-, and polynucleotides. J. Biol. Chem. 251, 7240-7250.

Kiefhaber, T., Rudolph, R., Kohler, H.H., and Buchner, J. (1991). Protein aggregation in vitro and in vivo: a quantitative model of the kinetic competition between folding and aggregation. Biotechnology (NY) 9, 825-829.

Kiledjian, M., Wang, X., and Liebhaber, S.A. (1995). Identification of two KH domain proteins in the alpha-globin mRNP stability complex. EMBO J. 14, 4357-4364.

Kim, J.H., Hahm, B., Kim, Y.K., Choi, M., and Jang, S.K. (2000). Protein-protein interaction among hnRNPs shuttling between nucleus and cytoplasm. J. Mol. Biol. 298, 395-405.

Klimek-Tomczak, K., Wyrwicz, L.S., Jain, S., Bomsztyk, K., and Ostrowski, J. (2004). Characterization of hnRNP K protein-RNA interactions. J. Mol. Biol. 342, 1131-1141.

Kolbel, K., Ihling, C., Kuhn, U., Neundorf, I., Otto, S., Stichel, J., Robaa, D., Beck-Sickinger, A.G., Sinz, A., and Wahle, E. (2012). Peptide backbone conformation affects the substrate preference of protein arginine methyltransferase I. Biochemistry 51, 5463-5475.

Kuhn, U., Nemeth, A., Meyer, S., and Wahle, E. (2003). The RNA binding domains of the nuclear poly(A)-binding protein. J. Biol. Chem. 278, 16916-16925.

Leffers, H., Dejgaard, K., and Celis, J.E. (1995). Characterisation of two major cellular poly( $\mathrm{rC}$ )-binding human proteins, each containing three K-homologous (KH) domains. Eur. J. Biochem. 230, 447-453.

Liu, Q. and Dreyfuss, G. (1995). In vivo and in vitro arginine methylation of RNA-binding proteins. Mol. Cell Biol. 15, 2800-2808.

Lynch, M., Chen, L., Ravitz, M.J., Mehtani, S., Korenblat, K., Pazin, M.J., and Schmidt, E.V. (2005). hnRNP K binds a core polypyrimidine element in the eukaryotic translation initiation factor $4 \mathrm{E}$ (elF4E) promoter, and its regulation of elF4E contributes to neoplastic transformation. Mol. Cell Biol. 25, 6436-6453.

Mackereth, C.D., Madl, T., Bonnal, S., Simon, B., Zanier, K., Gasch, A., Rybin, V., Valcarcel, J., and Sattler, M. (2011). Multi-domain conformational selection underlies pre-mRNA splicing regulation by U2AF. Nature 475, 408-411.

Makeyev, A.V. and Liebhaber, S.A. (2002). The poly(C)-binding proteins: a multiplicity of functions and a search for mechanisms. RNA 8, 265-278.

Maretzki, D., Kostic, M., Reimann, B., Schwarzer, E., and Rapoport, S.M. (1986). Maturation of rabbit reticulocytes: strong decline of the turnover of polyphosphoinositides. Biomed Biochim. Acta. 45, 1227-1236. 
Matunis, M.J., Michael, W.M., and Dreyfuss, G. (1992). Characterization and primary structure of the poly(C)-binding heterogeneous nuclear ribonucleoprotein complex K protein. Mol. Cell Biol. 12, 164-171.

Messias, A.C. and Sattler, M. (2004). Structural basis of singlestranded RNA recognition. Acc. Chem. Res. 37, 279-287.

Messias, A.C., Harnisch, C., Ostareck-Lederer, A., Sattler, M., and Ostareck, D.H. (2006). The DICE-binding activity of KH domain 3 of hnRNP $\mathrm{K}$ is affected by c-Src-mediated tyrosine phosphorylation. J. Mol. Biol. 361, 470-481.

Michael, W.M., Eder, P.S., Dreyfuss, G. (1997). The K nuclear shuttling domain: a novel signal for nuclear import and nuclear export in the hnRNP K protein. EMBO J. 16, 3587-3598.

Michael, W.M., Siomi, H., Choi, M., Pinol-Roma, S., Nakielny, S., Liu, Q., Dreyfuss, G. (1995). Signal sequences that target nuclear import and nuclear export of pre-mRNA-binding proteins. Cold Spring Harb. Symp. Quan. Biol. 60, 663-668.

Michelotti, E.F., Michelotti, G.A., Aronsohn, A.I., and Levens, D. (1996). Heterogeneous nuclear ribonucleoprotein $\mathrm{K}$ is a transcription factor. Mol. Cell Biol. 16, 2350-2360.

Moritz, B. and Wahle, E. (2014). Simple methods for the 3' biotinylation of RNA. RNA 20, 421-427.

Moumen, A., Masterson, P., O’Connor, M.J., and Jackson, S.P. (2005). hnRNP K: an HDM2 target and transcriptional coactivator of p53 in response to DNA damage. Cell 123, 1065-1078.

Moumen, A., Magill, C., Dry, K.L., and Jackson, S.P. (2013). ATM-dependent phosphorylation of heterogeneous nuclear ribonucleoprotein $\mathrm{K}$ promotes $\mathrm{p} 53$ transcriptional activation in response to DNA damage. Cell Cycle 12, 698-704.

Musco, G., Stier, G., Joseph, C., Castiglione Morelli, M.A., Nilges, M., Gibson, T.J., and Pastore, A. (1996). Three-dimensional structure and stability of the $\mathrm{KH}$ domain: molecular insights into the fragile X syndrome. Cell 85, 237-245.

Naarmann, I.S., Harnisch, C., Flach, N., Kremmer, E., Kuhn, H., Ostareck, D.H., and Ostareck-Lederer, A. (2008). mRNA silencing in human erythroid cell maturation: heterogeneous nuclear ribonucleoprotein $\mathrm{K}$ controls the expression of its regulator c-Src. J. Biol. Chem. 283, 18461-18472.

Naarmann, I.S., Harnisch, C., Muller-Newen, G., Urlaub, H., Ostareck-Lederer, A., and Ostareck, D.H. (2010). DDX6 recruits translational silenced human reticulocyte 15 -lipoxygenase mRNA to RNP granules. RNA 16, 2189-2204.

Naarmann-de Vries, I.S., Urlaub, H., Ostareck, D.H., and OstareckLederer, A. (2013). Caspase-3 cleaves hnRNP K in erythroid differentiation. Cell Death Dis. 4, e548.

Ong, S.E., Mittler, G., and Mann, M. (2004). Identifying and quantifying in vivo methylation sites by heavy methyl SILAC. Nat. Methods 1, 119-126.

Ostareck, D.H., Ostareck-Lederer, A., Wilm, M., Thiele, B.J., Mann, M., and Hentze, M.W. (1997). mRNA silencing in erythroid differentiation: hnRNP K and hnRNP E1 regulate 15-lipoxygenase translation from the $3^{\prime}$ end. Cell 89, 597-606.

Ostareck, D.H., Ostareck-Lederer, A., Shatsky, I.N., and Hentze, M.W. (2001). Lipoxygenase mRNA silencing in erythroid differentiation: The 3'UTR regulatory complex controls $60 \mathrm{~S}$ ribosomal subunit joining. Cell 104, 281-290.

Ostareck-Lederer, A. and Ostareck, D.H. (2012). Precision mechanics with multifunctional tools: how hnRNP K and hnRNPs E1/E2 contribute to post-transcriptional control of gene expression in hematopoiesis. Curr. Protein Pept. Sci. $13,391-400$.
Ostareck-Lederer, A., Ostareck, D.H., Standart, N., and Thiele, B.J. (1994). Translation of 15-lipoxygenase mRNA is inhibited by a protein that binds to a repeated sequence in the $3^{\prime}$ untranslated region. EMBO J. 13, 1476-1481.

Ostareck-Lederer, A., Ostareck, D.H., and Hentze, M.W. (1998). Cytoplasmic regulatory functions of the $\mathrm{KH}$-domain proteins hnRNPs K and E1/E2. Trends Biochem. Sci. 23, 409-411.

Ostareck-Lederer, A., Ostareck, D.H., Cans, C., Neubauer, G., Bomsztyk, K., Superti-Furga, G., and Hentze, M.W. (2002). c-Src-mediated phosphorylation of hnRNP $\mathrm{K}$ drives translational activation of specifically silenced mRNAs. Mol. Cell Biol. 22, 4535-4543.

Ostareck-Lederer, A., Ostareck, D.H., Rucknagel, K.P., Schierhorn, A., Moritz, B., Huttelmaier, S., Flach, N., Handoko, L., and Wahle, E. (2006). Asymmetric arginine dimethylation of heterogeneous nuclear ribonucleoprotein $\mathrm{K}$ by protein-arginine methyltransferase 1 inhibits its interaction with c-Src. J. Biol. Chem. 281, 11115-11125.

Pawlak, M.R., Scherer, C.A., Chen, J., Roshon, M.J., and Ruley, H.E. (2000). Arginine N-methyltransferase 1 is required for early postimplantation mouse development, but cells deficient in the enzyme are viable. Mol. Cell Biol. 20, 4859-4869.

Pfennig, N. and Lippert, K.D. (1966). Uber das Vitamin B12-Bedurfnis phototropher Schwefelbakterien. Arch. Mikrobiol. 55, 245-256.

Pinol-Roma, S., Choi, Y.D., Matunis, M.J., and Dreyfuss, G. (1988). Immunopurification of heterogeneous nuclear ribonucleoprotein particles reveals an assortment of RNA-binding proteins. Genes Dev. 2, 215-227.

Reimann, I., Huth, A., Thiele, H., and Thiele, B.J. (2002). Suppression of 15-lipoxygenase synthesis by hnRNP E1 is dependent on repetitive nature of LOX mRNA 3'-UTR control element DICE. J. Mol. Biol. 315, 965-974.

Revil, T., Pelletier, J., Toutant, J., Cloutier, A., and Chabot, B. (2009). Heterogeneous nuclear ribonucleoprotein $\mathrm{K}$ represses the production of pro-apoptotic Bcl-xS splice isoform. J. Biol. Chem. 284, 21458-21467.

Schuck, P. (2000). Size-distribution analysis of macromolecules by sedimentation velocity ultracentrifugation and lamm equation modeling. Biophys. J. 78, 1606-1619.

Shamoo, Y., Abdul-Manan, N., Williams, K.R. (1995). Multiple RNA binding domains (RBDs) just don't add up. Nucleic Acids Res. 23, 725-728.

Sidiqi, M., Wilce, J.A., Vivian, J.P., Porter, C.J., Barker, A., Leedman, P.J., and Wilce, M.C. (2005). Structure and RNA binding of the third KH domain of poly(C)-binding protein 1. Nucleic Acids Res. 33, 1213-1221.

Siomi, H., Matunis, M.J., Michael, W.M., and Dreyfuss, G. (1993). The pre-mRNA binding K protein contains a novel evolutionarily conserved motif. Nucleic Acids Res. 21, 1193-1198.

Tang, J., Frankel, A., Cook, R.J., Kim, S., Paik, W.K., Williams, K.R., Clarke, S., and Herschman, H.R. (2000). PRMT1 is the predominant type I protein arginine methyltransferase in mammalian cells. J. Biol. Chem. 275, 7723-7730.

Thisted, T., Lyakhov, D.L., and Liebhaber, S.A. (2001). Optimized RNA targets of two closely related triple KH domain proteins, heterogeneous nuclear ribonucleoprotein $\mathrm{K}$ and alphaCP-2KL, suggest Distinct modes of RNA recognition. J. Biol. Chem. 276, 17484-17496.

Thomas, M., White, R.L., and Davis, R.W. (1976). Hybridization of RNA to double-stranded DNA: formation of R-loops. Proc. Natl. Acad. Sci. USA 73, 2294-2298. 
Tomonaga, T. and Levens, D. (1996). Activating transcription from single stranded DNA. Proc. Natl. Acad. Sci. USA 93, 5830-5835.

Tripsianes, K., Chu, N.K., Friberg, A., Sattler, M., and Becker, C.F. (2013). Studying weak and dynamic interactions of posttranslationally modified proteins using expressed protein ligation. ACS Chem. Biol. 9, 347-352.

Valverde, R., Edwards, L., and Regan, L. (2008). Structure and function of KH domains. FEBS J. 275, 2712-2726.

van Leyen, K., Duvoisin, R.M., Engelhardt, H., and Wiedmann, M. (1998). A function for lipoxygenase in programmed organelle degradation. Nature 395, 392-395.

Venables, J.P., Koh, C.S., Froehlich, U., Lapointe, E., Couture, S., Inkel, L., Bramard, A., Paquet, E.R., Watier, V., Durand, M., et al. (2008). Multiple and specific mRNA processing targets for the major human hnRNP proteins. Mol. Cell Biol. 28, 6033-6043.
Wahle, E., Lustig, A., Jeno, P., and Maurer, P. (1993). Mammalian poly(A)-binding protein II. Physical properties and binding to polynucleotides. J. Biol. Chem. 268, 2937-2945.

Wang, Z.X. (1995). An exact mathematical expression for describing competitive binding of two different ligands to a protein molecule. FEBS Lett. 360, 111-114.

Wongsurawat, T., Jenjaroenpun, P., Kwoh, C.K., and Kuznetsov, V. (2012). Quantitative model of R-loop forming structures reveals a novel level of RNA-DNA interactome complexity. Nucleic Acids Res. 40, e16.

Zhang, X. and Cheng, X. (2003). Structure of the predominant protein arginine methyltransferase PRMT1 and analysis of its binding to substrate peptides. Structure $11,509-520$.

Supplemental Material: The online version of this article (DOI 10.1515/ hsz-2014-0146) offers supplementary material, available to authorized users. 